\title{
Digital Architecture - Results from a Gap Analysis
}

Johanna Oxstrand, Kenneth Thomas, and Kirk Fitzgerald

September 2015



U.S. Department of Energy

Office of Nuclear Energy 


\section{DISCLAIMER}

This information was prepared as an account of work sponsored by an agency of the U.S. Government. Neither the U.S. Government nor any agency thereof, nor any of their employees, makes any warranty, expressed or implied, or assumes any legal liability or responsibility for the accuracy, completeness, or usefulness, of any information, apparatus, product, or process disclosed, or represents that its use would not infringe privately owned rights. References herein to any specific commercial product, process, or service by trade name, trade mark, manufacturer, or otherwise, does not necessarily constitute or imply its endorsement, recommendation, or favoring by the U.S. Government or any agency thereof. The views and opinions of authors expressed herein do not necessarily state or reflect those of the U.S. Government or any agency thereof. 
INL/EXT-15-36662

Revision 0

\title{
Digital Architecture - Results from a Gap Analysis
}

\author{
Johanna Oxstrand, Kenneth Thomas, and Kirk Fitzgerald
}

September 2015

\begin{abstract}
Idaho National Laboratory
LWRS Program

Idaho Falls, Idaho 83415
\end{abstract}

http://www.inl.gov

Prepared for the

U.S. Department of Energy

Office of Nuclear Energy

Under DOE Idaho Operations Office

Contract DE-AC07-05ID14517 


\section{SUMMARY}

The Digital Architecture Pilot Project aims to provide a systematic means of planning upgrades to the information technology (IT) infrastructure that will be needed to support nuclear utilities as they move forward with deployment of advanced technologies. The project is a part of the instrumentation, information, and control (II\&C) systems technologies pathway of the Department of Energy's Light Water Reactor Sustainability (LWRS) Program.

The digital architecture is defined as a collection of IT capabilities needed to support and integrate a wide spectrum of real time digital capabilities for NPP performance improvements. Digital architecture can be thought of as an integration of the separate instrumentation and control (I\&C) and information systems already in place in nuclear power plants (NPPs), brought together for the purpose of creating new levels of automation in NPP work activities.

The goal of the digital architecture research is to develop a methodology for mapping NPP operational and support activities into the digital architecture, which includes the development of a planning model for advanced information and control architecture.

The model development began with identification of infrastructure and user requirements. The identified set of requirements was reported in Thomas and Oxstrand (2015). The next step in model development was to determine the current state of digital architecture at typical NPPs through a gap analysis. The goal of the gap analysis was to determine to what extent the NPPs can support the future digital technology environment with their existing I\&C and IT structure and where gaps exist with respect to the full deployment of technology over time. The gap analysis was conducted by two parallel activities (1) site visits and (2) a web-based survey. The methodology, results, and conclusions from the gap analysis are described in this report.

The identified gaps are:

1. Plans for plant wide deployment of wireless network

2. Understanding of limitations and possibilities of wireless network

3. Use of existing technologies for real-time collaboration

4. Plans for integrating advanced technologies in the outage control center

5. Plans for modernizing the main control room

6. Use of online monitoring technologies. 


\section{ACKNOWLEDGEMENTS}

The authors would like to express special gratitude to the following people for their collaboration and support of this research effort:

Michael Grigsby, Bruce Gordon, and Carlos Williams at Arizona Public Service's Palo Verde Nuclear Generating Station; Jeff Keith, Al Sweney, Nick Bartcher, Richard Cook, Jennifer James at Duke Energy; and Ed Greco, Guy Bradley, Khuzema Bhagat, Shirley Counts, Jan Geib, Dennis Gehr, and Willie Vogt at SCANA's Virgil C. Summer Nuclear Generating Station.

In addition, the authors would also like to thank all who participated in the gap analysis. 


\section{CONTENTS}



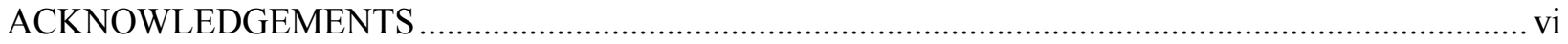



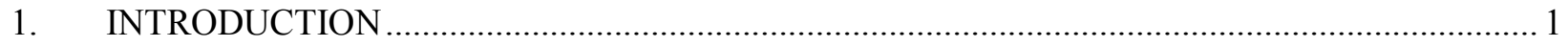

1.1 Development Partners in the Digital Architecture Pilot Project ........................................... 2



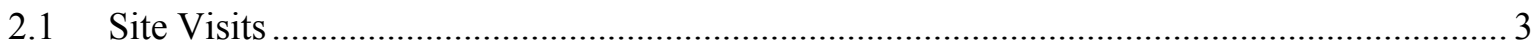



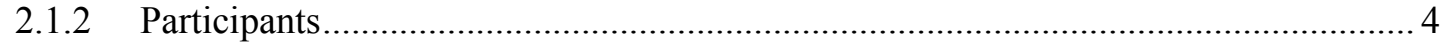

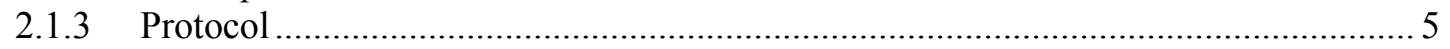

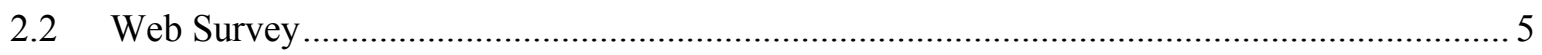

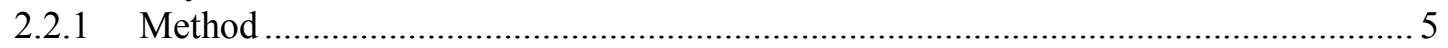

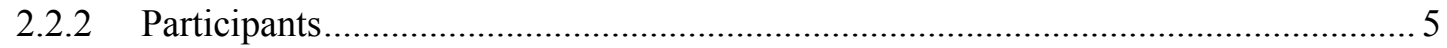

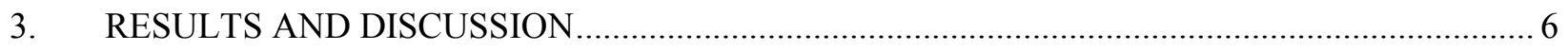

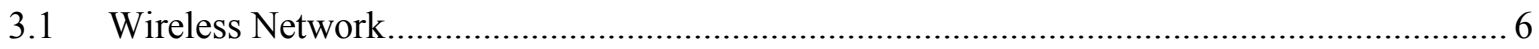

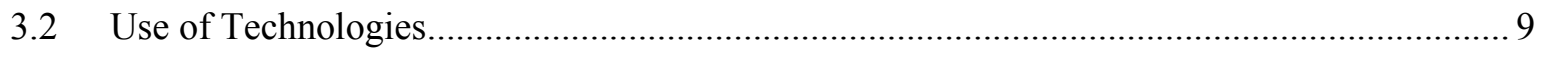

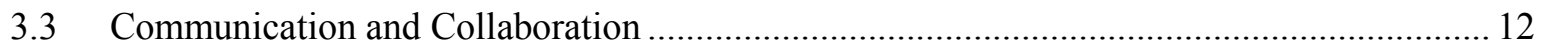

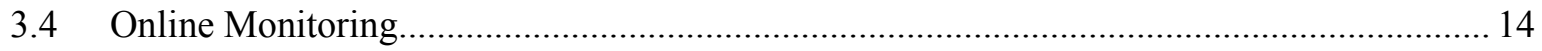

3.5 Control Center Modernizations ............................................................................................. 16

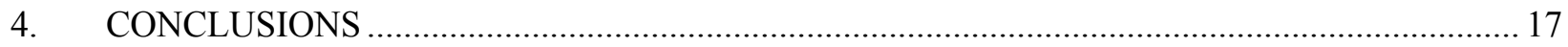



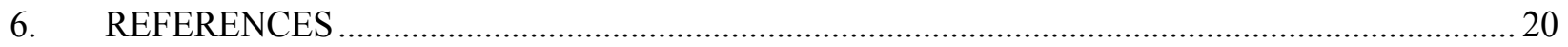

Appendix A Onsite Gap Analysis Application and Technology Checklist/Inventory............................ 21



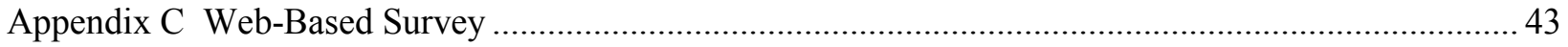

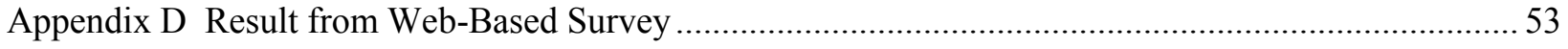




\section{FIGURES}

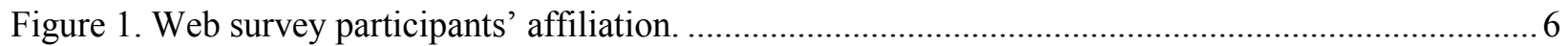

Figure 2. Survey of technologies used at participants' sites. .................................................................... 7

Figure 3. Survey results of wireless network deployment at plants..................................................... 8

Figure 4. Survey results of where (or will) the wireless network be used.............................................. 8

Figure 5. The view of cybersecurity as a limiting factor to deploy wireless network. ............................ 9

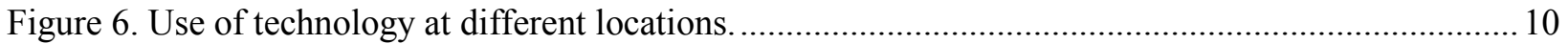

Figure 7. Percent of participants that will use the technologies for business purposes. .......................... 11

Figure 8. Percent of participants that will use the technologies in the outage control center.................... 12



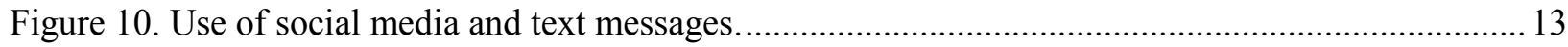

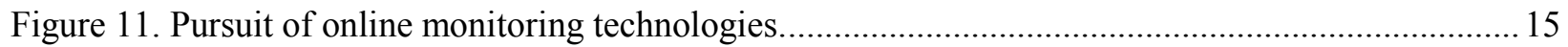

Figure 13. Survey results of pursuant advanced control room technologies. ........................................ 17

\section{TABLE}

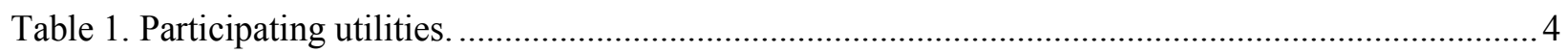



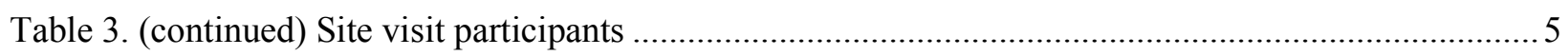




\section{ACRONYMS}

DOE Department of Energy

EPRI the Electric Power Research Institute

eWP electronic work packages

FSAR final safety analysis report

FY fiscal year

I\&A infrastructure and applications

I\&C instrumentation and control

II\&C instrumentation, information, and control

INPO Institute of Nuclear Power Operations

IT information technology

LWR light water reactor

LWRS light water reactor sustainability

MCR main control room

MDM mobile device management

NITSL Nuclear Information Technology Strategic Leadership

NPP nuclear power plants

NQA Nuclear Quality Assurance

OCC outage control center

OLM online monitoring

PI plant information

QR quick response

RFID radio-frequency identification

SMS short message service

SSL secure sockets layer

TSC technical support center

VOIP voice over internet protocol

VPN virtual private network

WEC work execution center

WMS work management system 


\section{Digital Architecture - Results from a Gap Analysis 1. INTRODUCTION}

The Department of Energy (DOE) sponsored the Light Water Reactor Sustainability (LWRS) Program that provides the technical foundations for licensing and managing the long-term, safe, and economical operation of current U.S. nuclear power plants (NPPs). A major objective of the LWRS program is the development of a seamless digital environment for plant operations and support by integrating information from plant systems with plant processes for nuclear workers through an array of interconnected technologies. This includes technologies to improve nuclear worker efficiency and human performance to offset a range of plant surveillance and testing activities with new online monitoring (OLM) technologies; improve command, control, and collaboration in settings such as outage control centers and work execution centers; and improve operator performance with new operator support technologies for the control room (Hallbert and Thomas 2014).

Within the LWRS Program, the instrumentation, information, and control (II\&C) systems technologies pathway addresses a broad range of digital technologies targeted at creating work efficiencies and improving plant performance. These technologies are developed in a series of 18 pilot projects and include applications that address mobile workers, outage management, OLM of components and structures, and modernized control rooms. The long-term goal is to transform the operating model of the NPPs from one that is highly reliant on a large staff performing mostly manual activities to an operating model based on highly integrated technology with a smaller staff. This digital transformation is critical to addressing an array of issues facing the plants, including aging of legacy analog systems, potential shortage of technical workers, ever-increasing expectations for nuclear safety improvement, and relentless pressure to reduce cost.

The future vision for the II\&C technologies is based on a future digital architecture that is a logical extension of the information technology (IT) infrastructure that is typically in place for NPPs today. Therefore, the Digital Architecture Pilot Project was defined to provide a systematic means of planning upgrades to the IT infrastructure that will be needed to support whatever combination of II\&C pilot project technologies are selected for implementation by a nuclear utility.

The digital architecture is defined as a collection of IT capabilities needed to support and integrate a wide-spectrum of real-time digital capabilities for NPP performance improvements. The digital architecture can be thought of as an integration of the separate instrumentation and control (I\&C) and information systems already in place in NPPs, brought together for the purpose of creating new levels of automation in NPP work activities. In some cases, it might be an extension of the current communication systems, which will provide digital communications where it is currently analog only.

This collection of IT capabilities must in turn be based on a set of user requirements that need to be supported for the interconnected technologies to operate in an integrated manner. These requirements, simply put, are a statement of the digital work functions that will be exercised in a fully implemented seamless digital environment and how much they will be used.

The goal of the digital architecture research is to develop a methodology for mapping NPP operational and support activities into the digital architecture, which includes the development of a planning model for advanced information and control architecture. The planning model should be developed at a level of detail that is useful to the industry. In other words, not so detailed that it specifies specific protocols and not so vague that it is only provides a high-level description of technology. 
To develop the model, the researchers first had to identify a set of user requirements that must be supported for the interconnected technologies to operate in an integrated manner. These requirements are a statement of the digital work functions that will be exercised in a fully implemented seamless digital environment and how much these functions will be used. The researchers developed an initial set of user requirements, which was published in March 2015 (Thomas and Oxstrand 2015). The requirements were grouped into four areas of NPP digital technologies:

1. Mobile Technology for NPP Field Workers

2. Control Centers

3. Main Control Room

4. Automated Plant Functions.

The next step toward the model development was to determine the current state of digital architecture at typical NPPs. To investigate the current state, the researchers conducted a gap analysis to determine to what extent the NPPs can support the future digital technology environment with their existing I\&C and IT structure, and where gaps exist with respect to the full deployment of technology over time. The methodology, results, and conclusions from the gap analysis are described in this report.

The results from the gap analysis were used to prioritize where focus is needed in defining and providing guidance for enhancing the digital architecture of nuclear plants. The results will also be key input to the development of a guidance document for implementing the digital architecture conceptual model. The methods used in each of the two parts of the gap analysis are described in Section 2, Gap Analysis.

This report addresses Milestone M3LW-15IN0603124 - Complete a report documenting the gap analysis between current typical instrumentation and controls and information technology capabilities in NPPs versus those documented in the digital architecture requirements report.

\subsection{Development Partners in the Digital Architecture Pilot Project}

The digital architecture pilot project has two major development partners: the Nuclear Information Technology Strategic Leadership (NITSL), and the Electric Power Research Institute (EPRI). Each partner provides technical expertise, review of project data and findings, and access to the utility membership for consultation and data collection.

NITSL is a forum to provide leadership and strategic guidance for information technology in the nuclear industry (https://www.nitsl.org/default.aspx). The goal of NITSL is to be recognized by the nuclear industry as the authoritative source for leadership and strategic guidance related to nuclear business IT and plant technology systems pertinent to safe, secure, reliable, and cost effective nuclear power generation. This can be achieved by information sharing through benchmarks, operating experience, and workshops. NITSL coordinates a consistent direction in industry-wide initiatives, and serves as an interface for communications with regulators and industry groups. NITSL is a topical area within the Institute of Nuclear Power Operations (INPO). INPO receives primary governance and oversight through INPO and the Nuclear Strategic Issues Advisory Committee. Ultimately, these bodies have overall strategic direction and authority over the organization.

The current functional and topical focus areas of NITSL provide strategic direction and support for the following four core process initiatives distinct to nuclear power generation:

- Software quality assurance

- Cybersecurity for nuclear power reactors

- Digital control systems 
- Infrastructure and applications (I\&A).

The I\&A committee has agreed to collaborate in the Digital Architecture Pilot Project by sponsoring working meetings at the annual NITSL workshops and conducting periodic conference calls with their member utilities to provide data and requirements needed by the various research activities. The I\&A committee has provided such opportunities for the past 2 years and plan to continue support for this work through the remaining project tasks. In addition, certain members of the I\&A committee have hosted benchmark trips for the gap analysis and will continue to actively support the future project tasks of developing the digital architecture planning model and the subsequent guidelines for using the model.

EPRI conducts research, development, and demonstration relating to the generation, delivery, and use of electricity for the benefit of the public. A significant part of EPRI's work is in support of nuclear energy, including the development of new technologies for the currently operating nuclear fleet. EPRI serves as the primary research organization for the nuclear power industry and conducts research in virtually all aspects of nuclear plant operations and support. EPRI has conducted research in the area of digital technology for decades and has produced numerous technical reports and guideline documents in this area. Many of these are accepted by the nuclear power industry as authoritative references and preferred methodologies for the technical topics they address. Some are endorsed by the Nuclear Regulatory Commission.

EPRI has contributed to and participated in many of the LWRS program II\&C pilot projects over the past four years and these collaborations are ongoing. The digital architecture pilot project is one project where collaboration is mutually beneficial. EPRI recognizes that the concepts of a digital architecture are foundational to the integration of digital technologies within a nuclear plant to maximize improvement in plant performance and work efficiency. EPRI is able to contribute significant expertise in topics related to digital architecture. Moreover, EPRI is able to engage nuclear utility staff in the project effort through the EPRI-sponsored industry groups. For these reasons, EPRI has agreed to actively participate in the pilot project as a full research partner.

\section{GAP ANALYSIS}

To gather input from as many utilities as possible during the summer of 2015, researchers designed the gap analysis to be conducted in two parallel efforts: site visits, and web-based surveys. The overarching objective of the gap analysis was to map the previously defined digital architecture requirements (Thomas and Oxstrand 2015) to utilities existing IT Infrastructure with the purpose of identifying gaps between the current infrastructure and what is needed to sufficiently meet the requirements.

The site visits enabled in-depth discussions with staff to identify the current digital architecture at the site as well as any short-term or long-term plans to upgrade the IT and I\&C capabilities. In addition to the site visits, researchers utilized a web-based survey to gather information from utilities. The web survey was launched during the NITSL 2015 workshop in Minneapolis, July 2015. The NITSL Infrastructure and Application Committee hosted a special working meeting for the digital architecture pilot project to provide an opportunity for committee members to hear a status report on the project and to participate in the web survey.

\subsection{Site Visits}

\subsubsection{Method}

Based on the requirements identified by Thomas and Oxstrand (2015), the researchers developed an application and technology checklist. The checklist guided the discussion at each site visit to ensure that all major technology areas were covered. The checklist was also a means to perform a semi-structured inventory of the utility's current infrastructure. The complete checklist can be found in Appendix A, "Onsite Gap Analysis Application and Technology Checklist/Inventory." 


\subsubsection{Participants}

To obtain a representative sample of the U.S. operating nuclear fleet, three different types of nuclear utilities were approached about hosting a site visit and all three agreed. Table 1 describes the utilities visited during the study. The amount of participants at each visit and the participants' role at the utility varied. Figure 2 lists the site visit participants. The research team met with a total of eight participants during the visit at Utility 1, 4 participants at Utility 2, and 3 participants at Utility 3.

Table 1. Participating utilities.

\begin{tabular}{|l|l|}
\hline Utility & Type \\
\hline Utility1 & Single nuclear plant utility, multiple unit site \\
\hline Utility 2 & Large nuclear fleet utility, single and multiple unit sites \\
\hline Utility 3 & Single nuclear plant utility, single unit site \\
\hline
\end{tabular}

The different fleet types potentially represent several important circumstances regarding the information technology deployments as follows:

- Size of IT support organization, possibly reflecting the ability to spread costs over multiple units

- Focus of the IT organization on one or more units

- Standardization of practices and implementations across multiple units

- Whether the IT organization is onsite, offsite, or both

- Types of nuclear plants - pressurized water reactor and boiler water reactors

- Present state and direction of digital application implementation.

The researchers took note of whether any of these types of factors were particularly relevant in the findings from the benchmark visits. However, taken together, they provide a basis of confidence that the results of the benchmark visit can generally be extrapolated to the U.S. operating fleet. To be sure, there could be utilities with markedly different circumstances relative to the gap analysis, but that it is still likely that the findings in this report likely reflect the mainstream deployment state and technology direction of the U.S. operating fleet.

The one exception to this would be the degree of wireless deployment. None of these utilities were beyond an initial degree of deployment; whereas it is known that some other operating plants now have a substantial amount of wireless in the power block. That said, even these plants have not yet made extensive use of it in supporting mobile work technologies. Rather, the most prominent use of wireless today is for online monitoring of components.

Table 2. Site visit participants

\begin{tabular}{|l|l|}
\hline Utility & Participants \\
\hline Utility1 & IT Director \\
& IT Manager \\
& $\begin{array}{l}\text { IT Technology Consultants } \\
\text { IT Supervisor } \\
\text { Nuclear Cyber Compliance Specialist } \\
\text { Engineers }\end{array}$ \\
\hline Utility 2 & $\begin{array}{l}\text { Nuclear IT Develop \& Deploy Manager } \\
\text { Nuclear Process Systems Manager } \\
\text { Nuclear IT Infrastructure Group Manager } \\
\text { Nuclear IT Business Consultant }\end{array}$ \\
\hline
\end{tabular}


Table 2. (Continued) Site visit participants

\begin{tabular}{|l|l|}
\hline Utility & Participants \\
\hline Utility 3 & $\begin{array}{l}\text { Client Services Manager } \\
\text { Information Systems Client Manager } \\
\text { Assistant Plant Manager }\end{array}$ \\
\hline
\end{tabular}

\subsubsection{Protocol}

A structured interview was conducted of IT and engineering professionals that support the digital applications for the nuclear plants, from typical business processes to plant I\&C digital systems. The duration of the visits varied between four and eight hours. During the visits, researchers met with the participants in a conference room. After a roundtable of introductions, the visit began with purpose and objectives of the research effort and the gap analysis. Participants were asked to openly discuss the main groups of requirements, one requirement group at the time. Researchers used an overhead projector to share requirements tables with participants. Researchers intervened in the discussion if they needed to ask for clarification or to ensure the discussion stayed on topic. Throughout the discussion, researchers took notes which were later transcribed and analyzed.

\subsection{Web Survey}

In addition to the site visits, the researchers utilized a web-based survey to gather information from utilities. The web survey was launched during the NITSL 2015 workshop in Minneapolis, July 2015. The NITSL Infrastructure and Application Committee hosted a special working meeting for the digital architecture pilot project to provide an opportunity for committee members to hear a status report on the project and to participate in the web survey.

\subsubsection{Method}

Two hours of the working meeting were used for introducing the web survey, allowing time for the participants to fill out the survey, and for a general discussion related to the gap analysis. The survey was designed to gather detailed information to be incorporated with the insights gained from the site visits.

Examples of questions asked in the survey are listed below. The complete survey is found in Appendix C.

- What technologies are currently being used at your plant?

- Where/how is the technology being used (or is planned to be used)?

- Are you pursuing any mobile worker technologies?

- Are you pursuing OLM technologies?

- Are you pursuing advanced control room technologies?

- Do you see cybersecurity as a limiting factor for deploying wireless?

\subsubsection{Participants}

Thirteen participants participated in the web-based survey. As indicated in Figure 1, out of the 13 participants, 10 work at NPPs, two work in corporate offices, and one is an INPO employee (other). The participants represent eight different utilities, one corporate office, and INPO. The utilities represent a total of $45 \%$ of the light water reactor (LWR) units in the U.S. 


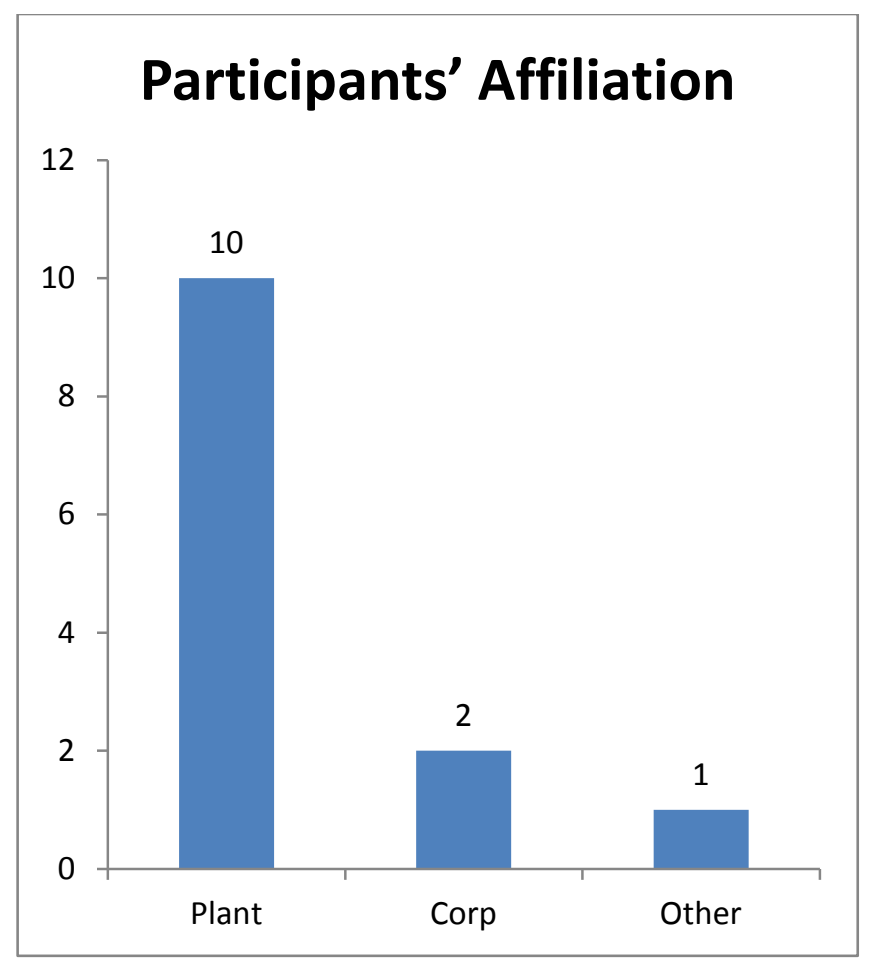

Figure 1. Web survey participants' affiliation.

\section{RESULTS AND DISCUSSION}

A content analysis was used on the information gathered during the site visits, which sorted the information into categories. Examples of categories used are: network, mobile devices, remote collaboration, online monitoring and electronic work packages, computer based procedures, and rounds. The site visits also captured information related to how technology is used or plant to be used at various work locations, such as outage control center (OCC), work execution center (WEC), and main control room (MCR). The complete set of information gathered during the site visits is located in Appendix B, "Results from Site Visits."

The result from the web survey was aggregated and summarized. This section presents a selection of the most interesting results. Appendix D, "Results from Web-Based Surveys," contains all results from the web surveys.

This section will present and discuss results from both studies. The discussion is divided into five focus areas: wireless network, use of technologies, communication and collaboration, OLM, and control center modernizations.

\subsection{Wireless Network}

Researchers created a summary chart describing which technologies are currently deployed, are planned to be deployed, or will most likely not be deployed by the utilities (see Figure 2). The three technologies most utilities have in place are real-time collaboration (92\%), large displays in control centers $(85 \%)$, and video cameras for monitoring plant work activities $(77 \%)$. It is interesting to note that wireless network is the technology least planned to deploy $(38 \%)$. 


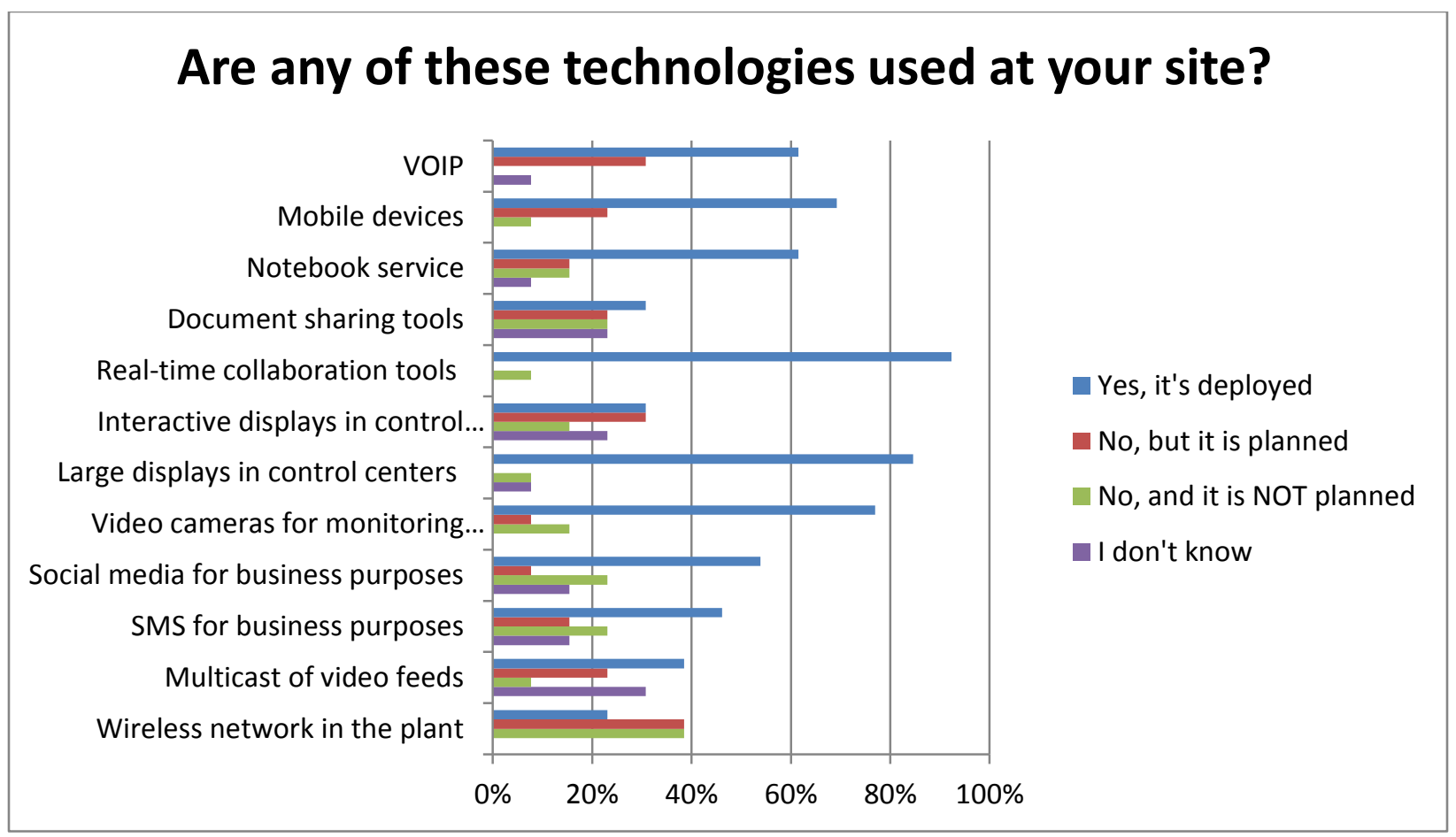

Figure 2. Survey of technologies used at participants' sites.

By focusing on the wireless network results (Figure 3 and Figure 4), it is apparent that $61 \%$ of the participants have either already deployed wireless network to some extent in the plant or are planning to do so. That means almost $40 \%$ of the participating utilities are not planning to deploy wireless in plants. One should note that none of the participants answered "I don't know" on the question about deploying wireless.

All participants will use wireless for business purposes (i.e., activities that do not directly impact the operation of the plant) and about $70 \%$ of the participants will use wireless network in the work execution centers and $62 \%$ in the outage control center (Figure 4). Again, none of the participants answered "I don't know" to the question about where wireless network would be used. 


\section{Is wireless network deployed?}

Yes, it's deployed

No, but it is planned

No, and it is NOT planned

don't know

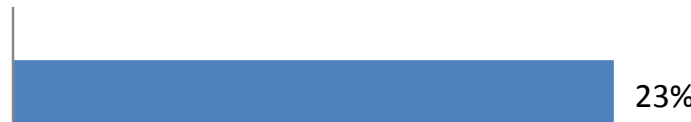

$23 \%$

Figure 3. Survey results of wireless network deployment at plants.

\section{Where is (or will) the wireless network be used?}

Emergency Response Facility (TSO/OSC/EOF)

Management Meeting Rooms

Work Control Centers

Outage Control Center

Business Purposes

I don't know

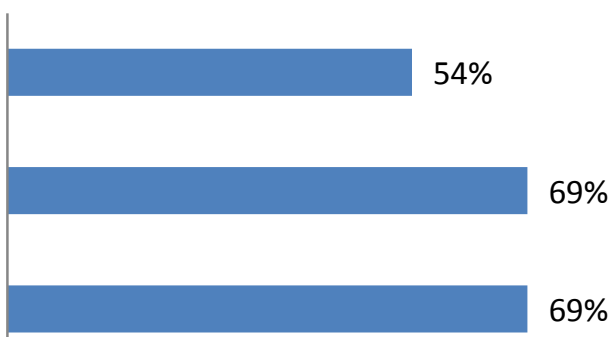

$62 \%$

Figure 4. Survey results of where (or will) the wireless network be used.

It is concerning that almost $40 \%$ of the participants report no plans for deployment. Wireless network is the largest enabler of real-time data access and collaboration. Many of the benefits of the pilot project capabilities will be foregone without wireless. The researchers conclude that both researchers and the industry need to investigate perceived and actual barriers to deployment of wireless and how to overcome 
these. Examples of identified barriers are cybersecurity and cost. A marketing campaign should be built to show how to best overcome the barriers.

As indicated by the results illustrated in Figure 5, the participants are quite evenly divided when asked about the perceived impact of cybersecurity in relation to deployment of wireless network. This begs for further research to clarify the concerns on wireless in the plant, what if anything it restricts, and how the risk can be mitigated. Some of this will be covered by future activities in the digital architecture research project. However, the majority of clarity and insights will likely be based on experience of the first movers. In addition, the industry needs to develop a consensus document covering what can and cannot be done with wireless from a cybersecurity standpoint.

\section{Do you see cybersecurity as a limiting factor for deploying wireless?}

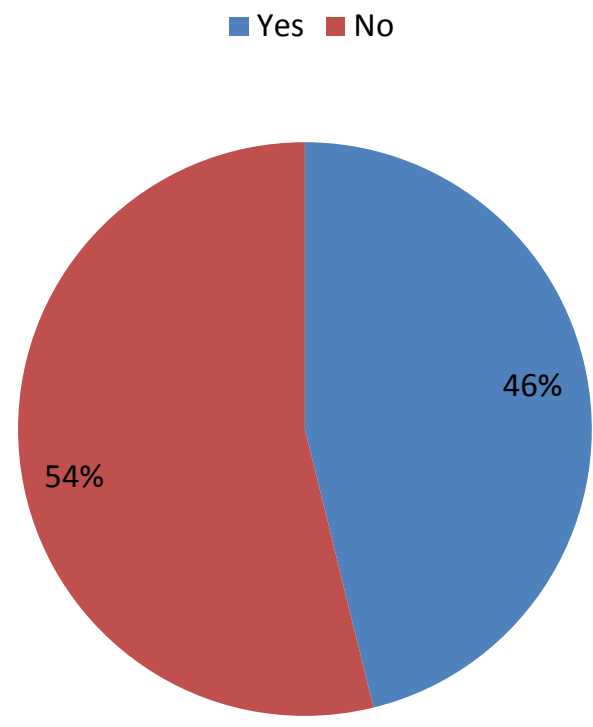

Figure 5. The view of cybersecurity as a limiting factor to deploy wireless network.

Both the site visits and the web survey concluded that the majority of wireless network currently deployed along with the planned deployments will mainly focus on the business process side of the plants (i.e., to be used for anything but conducting plant activities). Office buildings and major control centers will have wireless, which enables staff to use their laptops and tablets.

Another aspect of wireless network in the plant that is important for the utilities to consider is the fact that it is not enough to get $100 \%$ plant coverage. The capacity of the network should be studied to identify specific capacity needs in specific areas during specific times (e.g., during outage).

\subsection{Use of Technologies}

Just as with wireless network, the result indicates that most of the technologies covered in the gap analysis are or will be used for business purposes (i.e., to be used for work processes as opposed to plant work activities), as seen in Figure 6. With regard to future use of technology, the business purpose category most likely got a higher percentage due to the background of the participants in the gap analysis. The office areas are the purview of the IT professionals and plant engineering is responsible for changes 
in the power block. More progress in implementing digital applications in the power block will be helped by successful first mover examples and industry consensus documents.

Utilities are using the technologies for business purposes, which mean they will get an opportunity to familiarize themselves with the technologies, find ways to incorporate them into the everyday work activities, and identify direct and possible benefits and efficiencies to be gained. This will prove useful as the use of the technologies expands outside the offices and control centers.

If all participants indicated they use all the different types of technologies at one location, the bar in Figure 6 would be $100 \%$. The results show that the participants combined plan to use $61 \%$ of the suggested technologies for business purposes, which is by far the most common use for the technology. The second most common location to use the advanced technologies is in the outage control center (35\%). The specific results for technologies used for business purposes and in the outage control room are presented below (Figure 7 and Figure 8).



Figure 6. Use of technology at different locations. 


\section{Business Purposes}

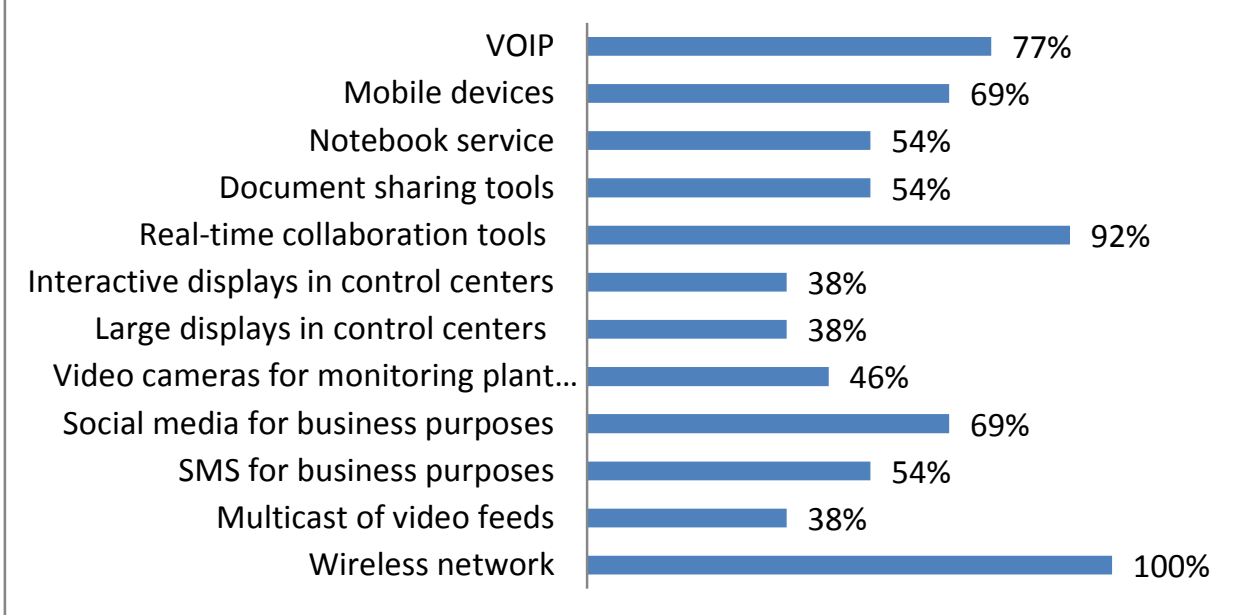

Figure 7. Percent of participants that will use the technologies for business purposes.

Figure 7 above focuses on the use of technologies for business purposes. The results from the survey state that use for business purposes will be the most common use of the technology. Next, after wireless network, the most of the participants anticipate using real-time collaboration (92\%), VOIP (77\%), social media (69\%), and mobile devices (69\%) for business purposes. About half the participants are using or planning to use notebook services, document sharing tools, and short message service (SMS) for business purposes (all technologies scored 54\%).

All three utilities participating in the site visit part of the study approved access of e-mails, calendar, and contacts via the untrusted mobile devices. The untrusted mobile devices utilize mobile device management (MDM) and containers to provide access to enterprise data and applications. MDM helps by managing the device including enforcing encryption, requiring a passcode and tracking location.

Container environments are used to build a protected virtual workspace to be deployed to mobile devices. The container with enterprise applications and content in an encrypted workspace houses productivity applications like email and access to content only available on the enterprise network. Instead of trusting the device itself, one should build trusted applications and environments to be used by the devices to increase its security posture. Currently, the only way to access work content via the device is using an application container environment using secure sockets layer (SSL) or token virtual private network (VPN) to remote into a work desktop.

Mobile devices are an example of tools supporting real-time collaboration, discussed below. Moving forward, mobile devices can/will be used to support plant activities as well as business purposes. Electronic work packages and procedures can be conducted using these devices. As the industry moves toward this aspect of mobile devices, it is important to consider how to deploy the devices. There are different approaches to consider (e.g., company provided devices versus personal devices and devices issued by the warehouse on a needs-basis versus devices permanently assigned to the individual workers).

About half the participants are using or planning to use notebook services, document sharing tools, and SMS for business purposes (these technologies scored 54\%). 


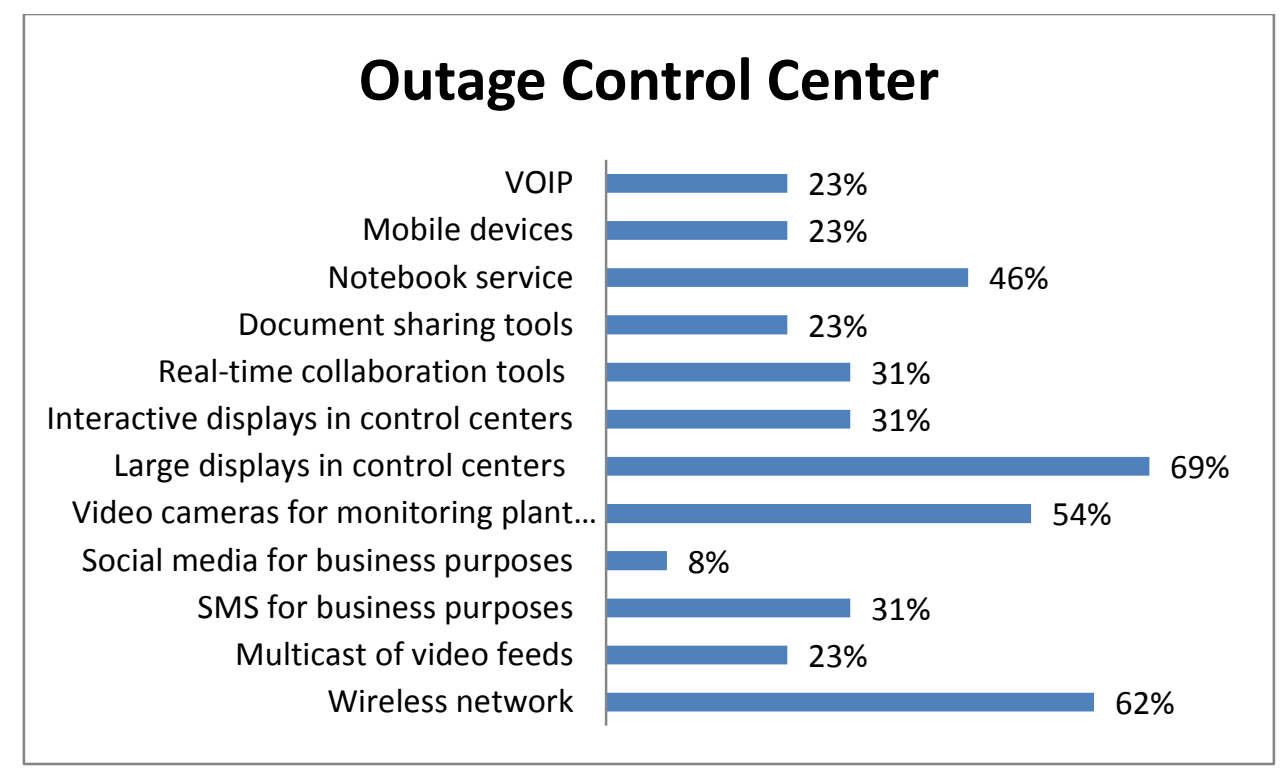

Figure 8. Percent of participants that will use the technologies in the outage control center.

The OCC was the second-most common place to use the technologies. Figure 8 illustrates the use of technologies used in the OCC. The most commonly used technologies are large displays (69\%), wireless network (62\%), video cameras to monitor plant work activities (54\%), and notebook services (46\%).

According to the gap analysis results, the technologies mainly used in the OCC all support collaboration, both within the OCC and with staff in other locations. Examples of use of these technologies are large displays and video cameras to monitor plant work activities. Interactive displays and real-time collaboration tools are also installed in the OCC. However, even though the technology can be used as collaboration tools, they are mostly set up to support one-direction information flows (i.e., not real-time collaboration). A two-way architecture is needed to support true real-time collaboration.

\subsection{Communication and Collaboration}

The researchers identified a gap in understanding how to effectively use the existing technologies to support real-time collaboration both when collaborating at the same location (e.g., in a meeting) or when collaborating with parties at separate locations (e.g., between the OCC and the WEC). Figure 9 below contains the data point for four collaboration technologies. Figure 9 illustrates the use of real-time collaboration tools, large displays, interactive displays, and mobile devices in relation to location/purpose (e.g., for business purposes or in control centers). About $70 \%$ of the participants have large displays in the OCC and 54\% in the WEC, and 38\% use them for business purposes. However, it seems that the large displays are mainly used for one-way communication of information rather than as a dynamic problem solving tool. In contrast, only $31 \%$ of the participants use interactive displays in the OCC and $15 \%$ in the WEC. Interactive displays enable remote and real-time collaboration capabilities. By replacing the current large screen displays with interactive displays, it could potentially increase the use of real-time collaboration technologies in the plants. This is identified as a moderate gap between how the technologies are used today and how they should be used to reach their full potential.

One of the utilities in the gap analysis concluded that the plant staff did not utilize the available interactive displays to their full capacity. Instead, the displays were primarily used as projectors, which is the opposite of the original intent. The utility stated that the use of mobile devices and conferencing tools reduces the need for large interactive displays. The team can collaborate and share information in real time, both within the group located in the same room and with remotely located parties using their tablets and a web-based conferencing tool. 




Figure 9. Use of collaboration technologies.

The combination of the high rate of deployment of real-time collaboration tools and the low deployment rate of wireless indicates that the collaboration tools are used in office settings. The researchers would like to investigate this topic further to clarify what type of real-time collaborating tools are deployed (e.g., video-conferencing tools and interactive displays), and how easily it would be to move these tools into the field settings.

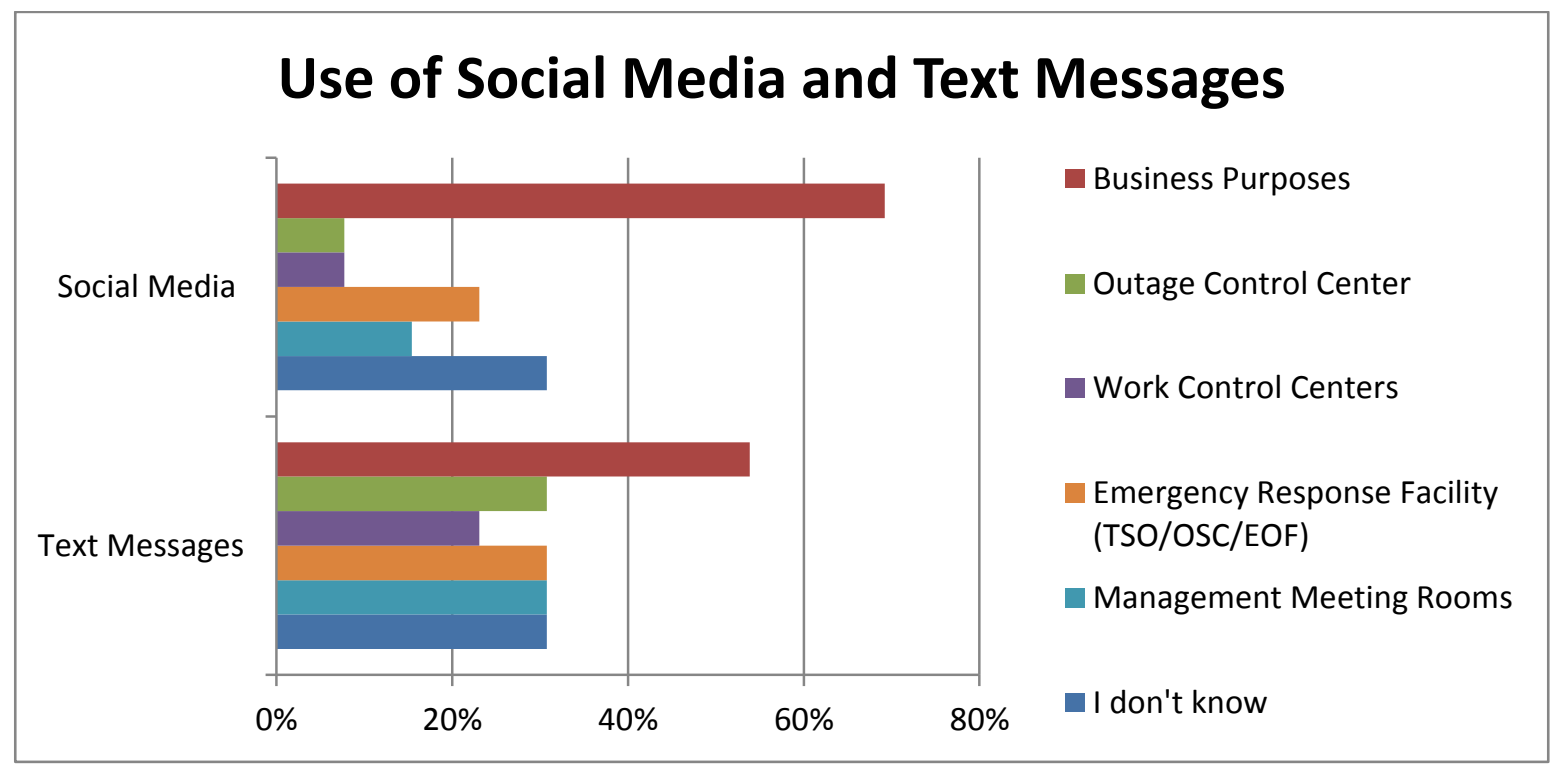

Figure 10. Use of social media and text messages. 
With mobile devices well established and planned, text messaging and social media are potentially powerful tools for sharing information and collaborating. It is likely that the utilities are using other real-time collaboration tools to meet needs that would be more efficiently met by utilizing text messaging and social media technologies. Figure 10 illustrates the use of social media and text messages.

Applications similar to social media applications used privately are commonly used on the business process side. However, these applications are not yet readily used in the plant. Several benefits are to be gained from these applications, such as the ability to rapidly share information to either a single individual or to a group, create groups for specific organizational functions, and coordinate tasks within and between groups.

Similar to social media-like applications, text messages are used for business purposes, but not to coordinate work activities in the plant. According to one of the utilities visited, text messages are severely under-utilized. This type of technology has the capability to create a more-accurate and efficient way of communicating. Text messages are near-time communication (i.e., between phone calls [real-time] and e-mails). The text messages will not interrupt a task in the same way a phone call potentially could, while at the same time it is more likely to get a rapid response to a text than to an e-mail. In addition, in contrast to phone calls, effective communication via text messages is possible in noisy environments.

This technology is not new in any way and it could easily be adapted and extended to support plant activities. Most workers in the nuclear industry have prior experience using both social media and text messages; hence, minimal training would be required before using these for work activities in the plant.

\subsection{Online Monitoring}

OLM is sometimes used for vibration monitoring of components, such as the reactor coolant pumps, turbine generators, and the turbine feed. However, most monitoring is still conducted as periodic surveillance activities by engineers in the plant. Some utilities would like to use more OLM to support preventive maintenance. Hardwired monitors are as effective as wireless ones, but that solution is very expensive. A wireless solution would make OLM cost-effective. However, for wireless OLM to be a viable option for the utilities, the industry must be ready to deploy wireless network in the power block. Another potential challenge that needs to be resolved is data storage. For example, a workable archiving strategy for data storage should be developed (e.g., looking at compression rates and sufficient granularity).

The results for the use of technology to offset manually performed work activities are consistent with researchers' prior beliefs. None of the participating utilities has wireless position monitoring at this time. As shown in Figure 11, 8\% have deployed continuous component condition monitoring technologies in lieu of periodic surveillances and $0 \%$ have deployed centralized OLM center to analyze data coming from monitoring technologies. However, $54 \%$ of the participants are planning to deploy both these technologies. Hence, the main finding related to OLM is that even though there is currently low deployment of the technologies the utilities are planning to deploy OLM technologies. 


\section{Are you pursuing online monitoring technologies?}

Yes, it's deployed $\quad$ No, but it is planned $\quad$ No, and it is NOT planned $\quad$ I don't know

$54 \%$



Continuous component condition monitoring technologies in lieu of periodic surveillances
$54 \%$

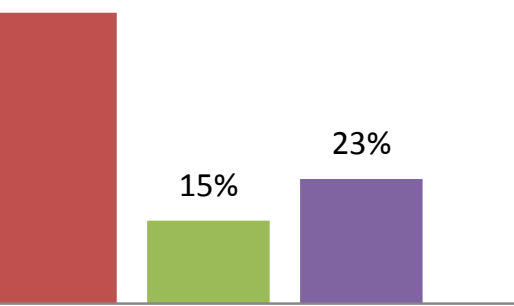

Centralized online monitoring center to analyze data coming from monitoring technologies

Figure 11. Pursuit of online monitoring technologies.

Surveys indicate that remote dose monitoring technologies is the most likely to be deployed to pursue offset manually performed work activities (46\%) (Figure 12). In contrast, wireless devices seem to be the least-popular technology to use to offset manually performed activities. None of the participants have deployed this technology and 38\% states that they do not plan to do so in the future. One should also note the large amount of participates that answered "I don't know." 


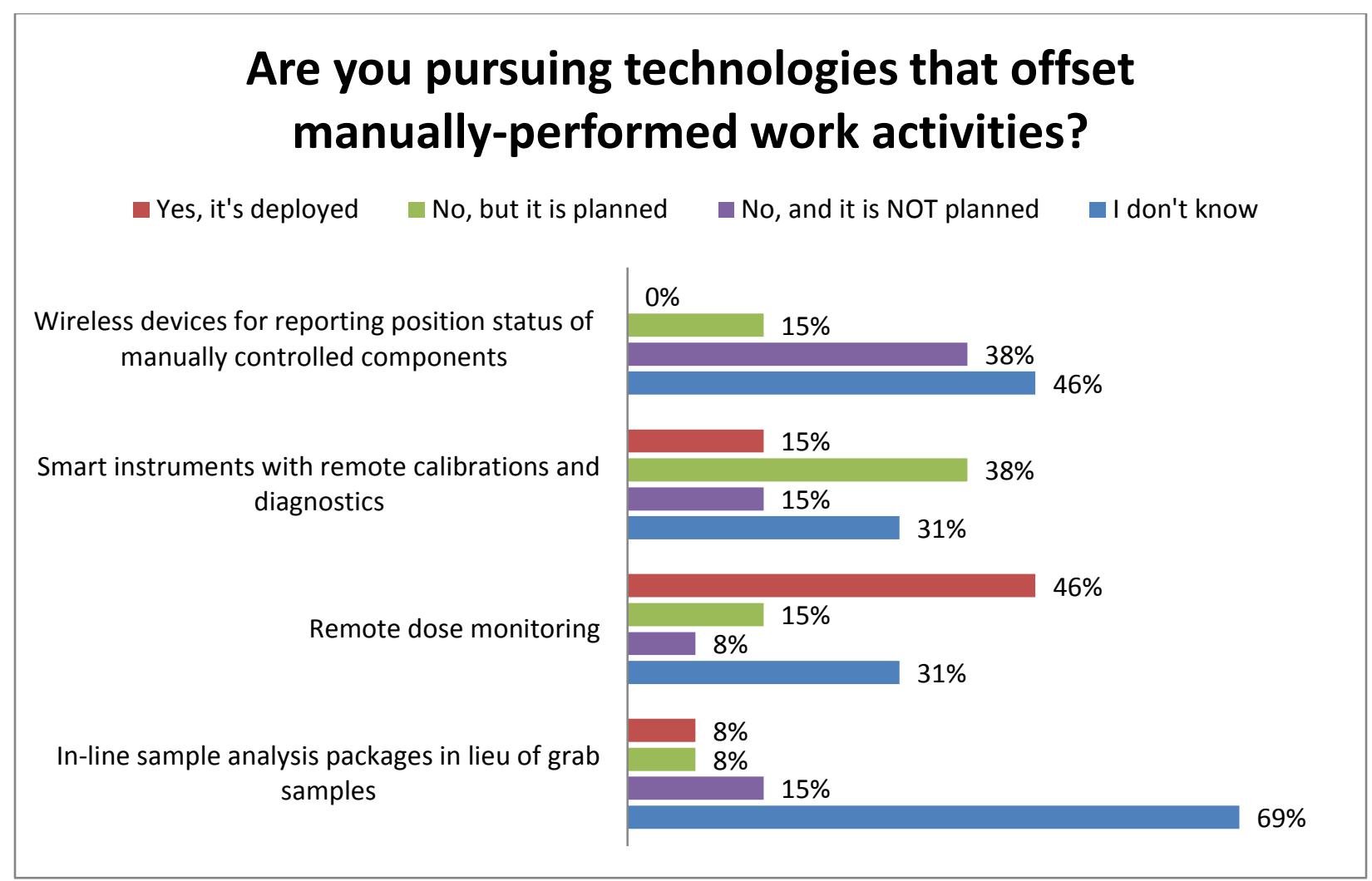

Figure 12. Technologies pursued to offset manually performed work activities.

\subsection{Control Center Modernizations}

As discussed earlier, the results from the web survey indicate that many of the technologies covered in the study are either currently used or are planned to be used in utilities' OCCs. This is in alignment with two of the utilities visited. These two utilities have quite modern OCCs where collaboration tools, such as interactive displays and web-based conferencing, are utilized. However, the third utility has a basic OCC and has no plans to modernize it. This indicates that for individual utilities or plants there could be a potential large gap between the current state of the OCC and what would be needed to support the infrastructure suggested in the LWRS program.

Figure 13 shows participating utilities with a low implementation rate of advanced technologies in current MCRs. However, it is interesting to point out that $62 \%$ are planning to deploy computer-based procedures and 54\% plan to deploy information-rich displays in the control room. This indicates a positive trend that supports the ongoing efforts in the LWRS program; however, this trend was not supported by the site visits. None of the utilities have plans to modernize their control rooms. This probably reflects an awareness of the technical, financial, and regulatory challenges in modernizing a control room. It again points to the need of success in this area by first movers to create confidence in the nuclear industry to bring modern digital technology into the control rooms. 


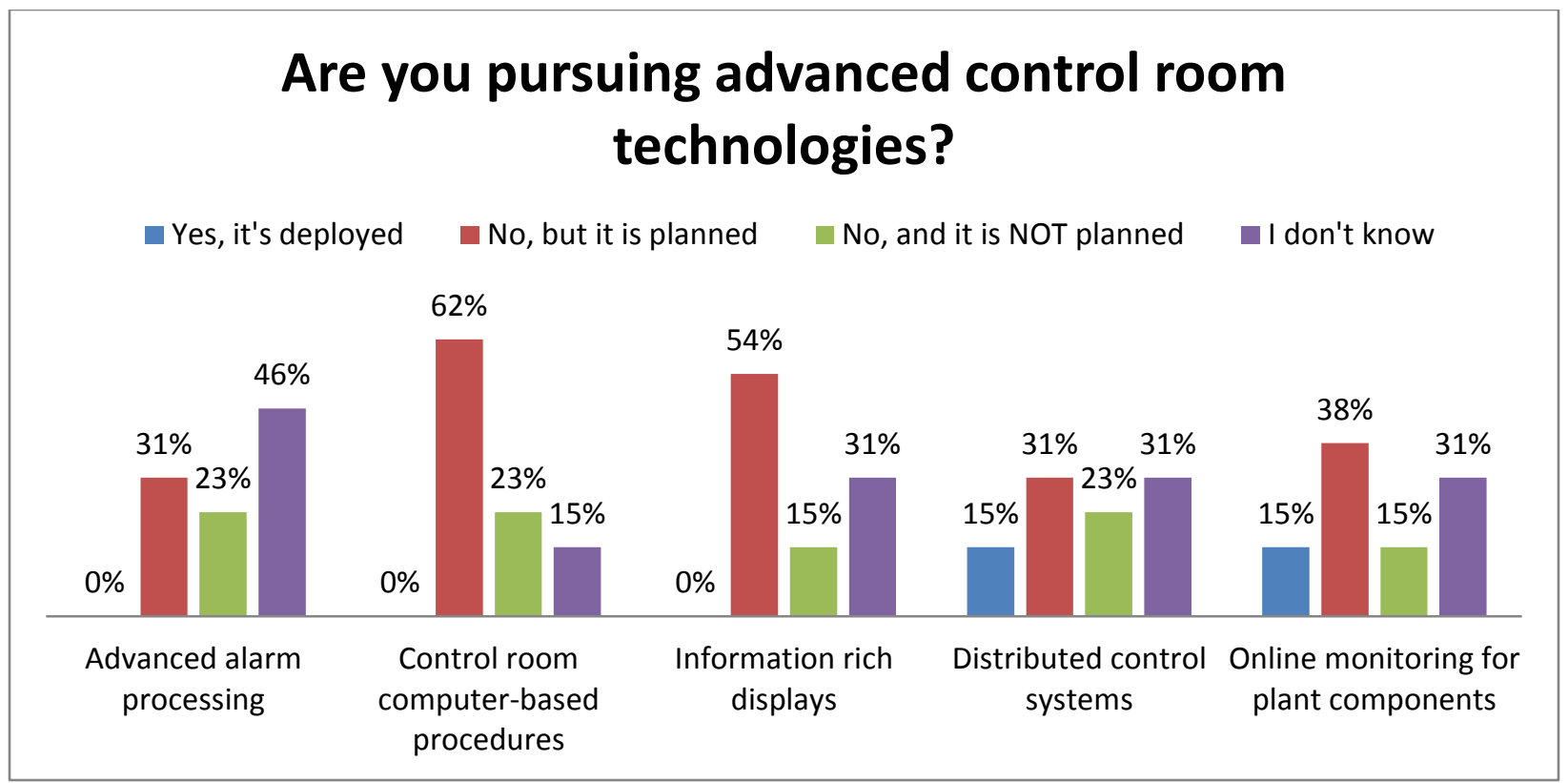

Figure 13. Survey results of pursuant advanced control room technologies.

The information represented in Figure 13 is not fully supported by previous research activities. For example, Joe, Boring, and Persensky (2012) conducted a survey targeting the industry's plans to modernize MCRs. The result indicates that the utilities plan to use various technologies in their MCR and that the most feasible and cost effective approach to MCR modernization is to partially modernize the I\&C and human-system interface rather than a full-scale modernization. In addition, the results from a study conducted by Le Blanc, Oxstrand, and Waicosky. (2012) shows that $66 \%$ of the six participating utilities have control room computer-based procedures included in their long-term vision.

Moving forward, researchers will follow on this potential gap (i.e., plans to modernize the MCRs). As indicated by Joe, Boring, and Persensky (2012) and Le Blanc, Oxstrand, and Waicosky (2012), there is already a movement toward control room modernizations. However, Successful demonstrations of benefit as well as a solid business case will most likely support the industry to move forward with the modernization activities. It is likely that the utilities will follow an incremental approach (as supported by the Joe, Boring, and Persensky. [2012] study) to properly manage risks involved with control room modernizations.

\section{CONCLUSIONS}

Six major gaps were identified based on the insights gained from the site visits and the web survey. The gaps are as follows:

1. Plans for plant wide deployment of wireless network

2. Understanding of limitations and possibilities of wireless network

3. Use of existing technologies for real-time collaboration

4. Plans for integrating advanced technologies in the OCC

5. Plans for modernizing the MCR

6. Use of OLM technologies.

The first gap is the most important and the most concerning gap. Further investigation should be conducted to gather more insights about the reasons for the limited plan to deploy wireless network 
covering the majority of the plant. The second gap relates to unresolved concerns of potential barriers to deploying wireless network. These barriers should be identified and addressed. Some barriers uncovered in the gap analysis are cybersecurity, cost, regulatory, and related to electromagnetic interference and radio frequency interference. There might be some misconceptions as to what the actual barriers really are, by virtue of the fact that some utilities are already doing what others believe cannot be done or is not allowed. There is a need for an industry document on what is allowable and prudent for putting wireless in the power block to support mobile worker technologies. The result from the gap analysis is thought to represent a lag in the industry hearing about the success stories. By demonstrating to the industry that these concerns do not have to be barriers, researchers in the LWRS program can help bridge this gap.

In order for an effective real-time collaboration to be established there is a need for an underlying architecture to support two-way information flow. Currently, many utilities have the technology (devices) needed for real-time collaboration, but not the architecture to support it. Real-time collaboration is a concept utilized by many of the pilot projects in the LWRS program since there is huge benefits to be gained from effective real-time collaboration, both when collaborating at the same location (e.g., in a meeting) or when collaborating with parties at separate locations. Real-time collaboration could support faster response time and reduce time spent on tracking down the most up to date information, which would be beneficial to control centers, such as the WCCs as well as the management meeting room.

Researchers also identified that replacing the current large screen displays with interactive displays, could potentially increase the use of real-time collaboration technologies in the plants, which would decrease the moderate gap between how the technologies are used today and how they should be used to reach their full potential.

Most of the participating utilities either have modernized their OCCs or plan to do so in the near future. However, some of the utilities stated that they have no plans to upgrade their OCCs to use any of the advanced technology suggested by the researchers. This indicates that for individual utilities or plants there could be a potential large gap between the current state of the OCC and what would be needed to support the infrastructure suggested in the LWRS program.

The MCR modernizations will be pursued when a solid business case is available to the utility senior managers. Part of building this case (and hence reduce the identified gap) is to demonstrate the potential benefits gained through the modernization. Parallel research activities in the II\&C pathway are currently collaborating with the industry to identify and demonstrate these benefits.

OLM technologies have a more obvious business case and they will likely make steady progress in implementation as more technology is developed. In addition, the early installations of OLM demonstrate benefits over periodic surveillances that are labor intensive. The identified gap between the current OLM technologies deployment level and the desired level of deployment will decrease as more of these technologies are being deployed by the utilities.

\section{PATH FORWARD}

To automate operating NPPs to their full potential, integration of digital technologies must extend beyond plant control and information systems to that of the domain of plant work processes and plant worker activities. This will require a plant digital architecture that is more encompassing than currently is available to the industry.

Even in today's more advanced plants, the digital architecture typically extends only to the major protection and integrated controls systems. Data architectures to support plant work processes are intentionally separate due to cybersecurity concerns. No comprehensive data schema is available that relates all plant functions in the context of their real-world relationships, thereby defining the needed data interfaces to conduct plant functions and support activities in an integrated manner. This architecture would define the following: 
- Systems that need to be integrated for robust plant protection and control

- Types of data busses and interfaces

- Cybersecurity requirements

- Failure and recovery requirements

- Necessary segmentation of the overall architecture to ensure independence of function and defense-in-depth

- Data relationships that are required to support plant functions, plant systems, plant processes, or plant worker activity

- External interfaces to enable remote operations and support activities, either at a fleet or industry level.

A planning model of the digital architecture will be developed based on the performance requirements documented in the digital architecture requirements report (Thomas and Oxstrand 2015). The model will relate these requirements to the corresponding IT infrastructure components and their respective capacity and performance requirements. For example, if a certain number of real-time remote collaboration sessions using streaming video are conducted concurrently, what is the required bandwidth for a wireless communication system and what is the required plant area coverage? In addition to requirements, constraints will also be identified such as electromagnetic compatibility concerns in the vicinity of sensitive electronic equipment.

The planning model will also be based on the information coming from this gap analysis. This information will inform the developers of the planning model of where the current information technology infrastructures need to be modified or expanded to support the requirements of the future digital technologies. It will also provide insights of where expansion of the digital architecture is constrained more by concerns about risk or uncertainty, rather than technological capability.

The various technical components of the planning model will be identified and scoped for development. The planning model must be flexible and modular, so that it can be implemented either partially or fully, depending on the need of the utility and the types of digital technologies they desire to implement. The planning model must also relate in a natural understandable manner to the existing information technology architectures found in today's operating NPPs.

The objective for fiscal year (FY) 2016 is to complete the development of the planning model. The results from the gap analysis will be used to prioritize the focus of the model and in defining and providing guidance for enhancing the digital architecture of nuclear plants. The researchers will work closely with industry partners to identify the current state of the utilities infrastructure and ensure the planning model supports the needs of the industry.

Finally, in FY 2017, a guidelines document for utilities to implement the digital architecture planning model will be developed to assist with the scoping effort for IT upgrades for the support of targeted digital technologies. This document will reflect the combined experience and expertise of the participating utilities in how to assess the desired performance levels of the digital technologies, as well as translate them to the performance requirements of the planning model in its implemented form. The results from the gap analysis will be key input to this document. As mentioned previously, the guidelines will allow for a graded approach so that only the components needed to support the targeted technologies should be considered. The guidelines will be general and flexible enough to fit within the respective utilities' corporate standards and policies for IT implementation. 


\section{REFERENCES}

Hallbert, B. P., K. D. Thomas, 2014, Advanced Instrumentation, Information, and Control System Technologies -Technical Program Plan for 2014, INL/EXT-13-28055, Rev 3, September 2014.

Joe, J.C., R.L. Boring, and J.J. Persensky, 2012, Commercial Utility Perspective on Nuclear Power Plant Control Room Modernizations, Proceedings of the 8th International Conference on Nuclear Plant Instrumentation, Control, and Human-Machine Interface Technologies (ANS NPIC \& HMIT 2012). San Diego, USA, 2012.

Le Blanc, K., J. Oxstrand, and T. Waicosky, T, 2012, A Model of Operator Interaction with Field Procedures: Insights for Computer-Based Procedures. Proceedings of the 8th International Conference on Nuclear Plant Instrumentation, Control, and Human-Machine Interface Technologies (ANS NPIC \& HMIT 2012). San Diego, USA, 2012.

Nuclear Information Technology Strategic Leadership (NITSL) Website, https:/www.nitsl.org/Shared\%20Documents/NITSL\%20Overview\%20OneSheet.pdf, Retrieved September 17, 2015.

Thomas, K. and J. Oxstrand, 2015, Digital Architecture Requirements, INL/EXT-15-34696, Rev. 0, March 2015. 
Appendix A

Onsite Gap Analysis Application and Technology Checklist/Inventory 


\section{Appendix A \\ Onsite Gap Analysis Application and Technology Checklist/Inventory}

\section{General Capabilities}

\begin{tabular}{|c|c|c|c|c|c|c|}
\hline $\begin{array}{l}\text { Control Center } \\
\text { Functions }\end{array}$ & Number & Max on Site & $\begin{array}{l}\text { Worker } \\
\text { Location }\end{array}$ & Collaboration & $\begin{array}{l}\text { Augmented } \\
\text { Reality }\end{array}$ & Voice \\
\hline Operations & 140 & 80 & 80 & 5 & 20 & 7 \\
\hline Maintenance & 200 & 160 & 160 & 8 & 40 & 10 \\
\hline Chemistry & 30 & 20 & 20 & 2 & 5 & 2 \\
\hline RP & 50 & 30 & 30 & 3 & 8 & 3 \\
\hline Engineering & 150 & 130 & 130 & 5 & 33 & 8 \\
\hline Security & 200 & * & * & * & * & 10 \\
\hline Safety Assurance & 30 & 25 & 25 & 2 & 6 & 2 \\
\hline Supply Chain & 75 & 60 & 60 & 3 & 15 & 4 \\
\hline Facilities & 25 & 20 & 20 & 2 & 5 & 1 \\
\hline Utility Total & 900 & 525 & 525 & 30 & 131 & 45 \\
\hline Augmentation Staff & 1000 & 700 & 700 & 0 & 175 & 50 \\
\hline Suppliers & 200 & 160 & 160 & 8 & 40 & 10 \\
\hline
\end{tabular}

\begin{tabular}{|l|l|}
\hline Technology/Process/Location & \\
\hline $\begin{array}{l}\text { Physical Network Infrastructure } \\
\text { (copper, fiber, wireless, etc.) }\end{array}$ & \\
\hline & \\
\hline Work Location & \\
\hline Collaboration & \\
\hline Augmented Reality & \\
\hline Voice & \\
\hline Questions to keep in mind: & \\
\hline Are the numbers real? & \\
\hline $\begin{array}{l}\text { How can we make this useful and } \\
\text { meaningful? }\end{array}$ & \\
\hline
\end{tabular}


Work Packages

\begin{tabular}{|c|c|c|c|c|c|}
\hline Work Instr. & No. in 1 Day & CCVs & Qual. Checks & M\&TE Checks & Controlled Doc. Downloads \\
\hline CBPs & 900 & 4500 & 1800 & 225 & 180 \\
\hline AWPs & 100 & 1000 & 0 & 0 & 0 \\
\hline Tag-Outs & 24 & 960 & 0 & 0 & 0 \\
\hline Ops Rounds & 800 & 0 & 800 & 0 & 0 \\
\hline Work Instr. & $\begin{array}{c}\text { Ad Hoc Job } \\
\text { Aids }\end{array}$ & Plant Data & Collaboration & Work Status & Progress Transactions \\
\hline CBPs & 450 & 4500 & 135 & 4500 & 180,000 \\
\hline AWPs & 0 & 0 & 0 & 1000 & \\
\hline Tag-Outs & 0 & 240 & 0 & 120 & \\
\hline Ops Rounds & 0 & 0 & 0 & 0 & \\
\hline
\end{tabular}

\begin{tabular}{|l|l|}
\hline Technology/Process/Location & \\
\hline $\begin{array}{l}\text { Physical Network Infrastructure } \\
\text { (copper, fiber, wireless, etc.) }\end{array}$ & \\
\hline Document Sharing & \\
\hline Access to Plant Data & \\
\hline Collaboration & \\
\hline $\begin{array}{l}\text { Reporting for Work Status and } \\
\text { Progress Transactions }\end{array}$ & \\
\hline CBP & \\
\hline AWP & \\
\hline Tag-Outs & \\
\hline Ops Rounds & \\
\hline Questions to keep in mind: & \\
\hline Are the numbers real? & \\
\hline $\begin{array}{l}\text { How can we make this useful and } \\
\text { meaningful? }\end{array}$ & \\
\hline
\end{tabular}




\section{Outage/Work Control Center}

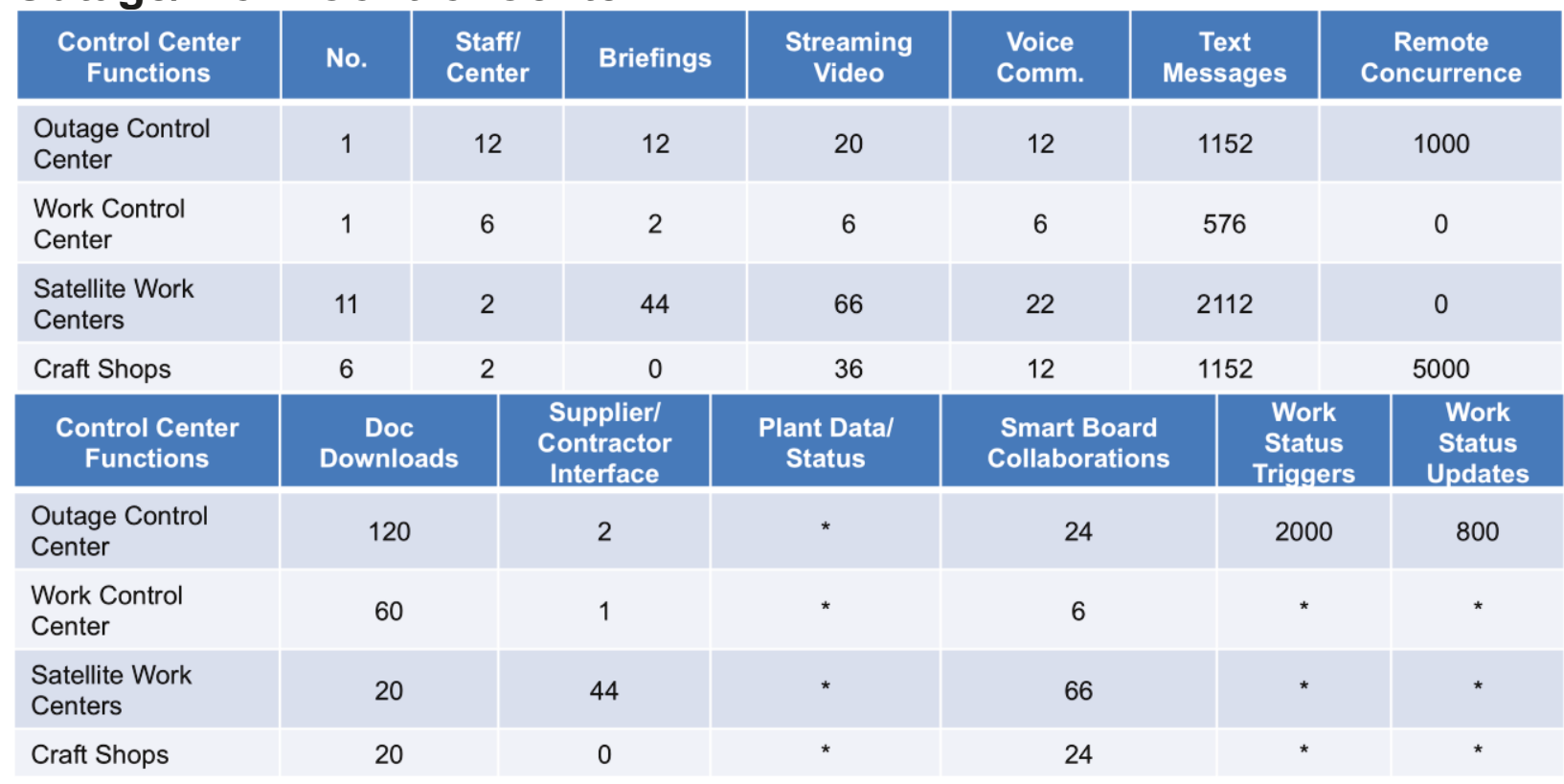

\begin{tabular}{|l|l|}
\hline Technology/Process/Location & \\
\hline $\begin{array}{l}\text { Physical Network Infrastructure } \\
\text { (copper, fiber, wireless, etc.) }\end{array}$ & \\
\hline Briefings & \\
\hline Streaming Video & \\
\hline Voice Communications & \\
\hline Text Messages & \\
\hline Remote Concurrence & \\
\hline Document Sharing & \\
\hline Access to Plant Data/Status & \\
\hline Large Screen/Smart Board & \\
\hline Work Status Triggers & \\
\hline Work Status Updates & \\
\hline Outage Control Center & \\
\hline Work Control Center & \\
\hline Satellite Work Centers & \\
\hline Craft Shops & \\
\hline Questions to keep in mind: & \\
\hline Are the numbers real? & \\
\hline How can we make this useful and & \\
\hline
\end{tabular}


Management Decision Support Centers

\begin{tabular}{|l|c|c|c|c|c|c|c|}
\hline $\begin{array}{l}\text { Management } \\
\text { Control Center }\end{array}$ & $\begin{array}{c}\text { Plant Datal } \\
\text { Status }\end{array}$ & Briefings & $\begin{array}{c}\text { Streaming } \\
\text { Video }\end{array}$ & $\begin{array}{c}\text { Voice } \\
\text { Comm. }\end{array}$ & $\begin{array}{c}\text { Text } \\
\text { Messages }\end{array}$ & $\begin{array}{c}\text { Doc. } \\
\text { Downloads }\end{array}$ & $\begin{array}{c}\text { Remote } \\
\text { Collaboration }\end{array}$ \\
\hline $\begin{array}{l}\text { Management } \\
\text { Decision Support } \\
\text { Center }\end{array}$ & 50 & 2 & 5 & 12 & 100 & 20 & 4 \\
\hline $\begin{array}{l}\text { Technical Support } \\
\text { Center }\end{array}$ & 500 & 15 & 2 & 15 & 150 & 20 & 2 \\
\hline $\begin{array}{l}\text { Operations Support } \\
\text { Center }\end{array}$ & 500 & 10 & 10 & 10 & 150 & 10 & 4 \\
\hline $\begin{array}{l}\text { Emergency } \\
\text { Operations Facility }\end{array}$ & 500 & 15 & 2 & 15 & 150 & 20 & 4 \\
\hline
\end{tabular}

\begin{tabular}{|l|l|}
\hline Technology/Process/Location & \\
\hline $\begin{array}{l}\text { Physical Network Infrastructure } \\
\text { (copper, fiber, wireless, } \text { etc.) }\end{array}$ & \\
\hline & \\
\hline Access to Plant Data/Status & \\
\hline Briefings & \\
\hline Streaming Video & \\
\hline Voice Communication & \\
\hline Text Messages & \\
\hline Document Sharing & \\
\hline Remote Collaboration & \\
\hline $\begin{array}{l}\text { Management Decision Support } \\
\text { Center }\end{array}$ & \\
\hline Technical Support Center & \\
\hline Operations Support Center & \\
\hline Emergency Operations Facility & \\
\hline Questions to keep in mind: & \\
\hline Are the numbers real? & \\
\hline $\begin{array}{l}\text { How can we make this useful } \\
\text { and meaningful? }\end{array}$ & \\
\hline
\end{tabular}


Operator Support Technologies

\begin{tabular}{|l|c|c|c|c|c|c|}
\hline $\begin{array}{l}\text { CR Team } \\
\text { Member }\end{array}$ & $\begin{array}{c}\text { Shared } \\
\text { Procedures }\end{array}$ & $\begin{array}{c}\text { Real-Time } \\
\text { Collaboration }\end{array}$ & $\begin{array}{c}\text { Video } \\
\text { Streaming }\end{array}$ & $\begin{array}{c}\text { Remote } \\
\text { Concurrence }\end{array}$ & $\begin{array}{c}\text { Work } \\
\text { Status } \\
\text { Update }\end{array}$ & $\begin{array}{c}\text { Doc. } \\
\text { Downloads }\end{array}$ \\
\hline $\begin{array}{l}\text { Reactor } \\
\text { Operator }\end{array}$ & 4 & 1 & 4 & 2 & 10 \\
\hline $\begin{array}{l}\text { Sr. Reactor } \\
\text { Operator }\end{array}$ & 4 & 1 & 4 & 1 & 10 & 2 \\
\hline Shift Supervisor & 4 & 1 & 2 & 0 & 10 & 2 \\
\hline STA & 4 & 1 & 0 & 0 & 0 & 2 \\
\hline Shift Manager & 4 & 1 & 2 & 0 & 0 & 2 \\
\hline $\begin{array}{l}\text { Equipment } \\
\text { Operators }\end{array}$ & 4 & 1 & 0 & 0 & 0 & 5 \\
\hline Shift Support & 0 & 0 & 0 & 0 & 10 \\
\hline
\end{tabular}

\begin{tabular}{|l|l|}
\hline Technology/Process/Location & \\
\hline $\begin{array}{l}\text { Physical Network Infrastructure } \\
\text { (copper, fiber, wireless, etc.) }\end{array}$ & \\
\hline & \\
\hline Shared Procedures & \\
\hline Real-Time Collaboration & \\
\hline Video Streaming & \\
\hline Remote Concurrence & \\
\hline Work Status Update & \\
\hline Document Sharing & \\
\hline Questions to keep in mind: & \\
\hline Are the numbers real? & \\
\hline $\begin{array}{l}\text { How can we make this useful and } \\
\text { meaningful? }\end{array}$ & \\
\hline
\end{tabular}




\section{Operator Interface Technologies}

\begin{tabular}{|c|c|c|c|c|c|c|c|}
\hline $\begin{array}{l}\text { Advanced } \\
\text { Technologies }\end{array}$ & DCS & $\begin{array}{l}\text { General } \\
\text { I\&C }\end{array}$ & $\begin{array}{l}\text { Alarm } \\
\text { Systems }\end{array}$ & $\begin{array}{l}\text { Process } \\
\text { Computer }\end{array}$ & $\begin{array}{l}\text { Monitoring } \\
\text { Systems }\end{array}$ & $\begin{array}{l}\text { Event } \\
\text { Recorder }\end{array}$ & $\begin{array}{l}\text { Supp. Info } \\
\text { Network }\end{array}$ \\
\hline $\begin{array}{l}\text { Computer-Based } \\
\text { Procedures }\end{array}$ & 4 & 4 & 0 & 4 & 0 & 0 & 4 \\
\hline Task-Based Displays & 4 & 4 & 4 & 4 & 0 & 0 & 4 \\
\hline Alarm Management & 0 & 0 & 400 & 4000 & 0 & 0 & 0 \\
\hline Group View Displays & 100 & 50 & 200 & 50 & 50 & 0 & 0 \\
\hline coss & 1000 & 500 & 5000 & 4000 & 100 & 4000 & 100 \\
\hline $\begin{array}{l}\text { Plant Status } \\
\text { Monitoring Systems }\end{array}$ & 100 & 50 & 0 & 50 & 0 & 0 & 1000 \\
\hline Virtual Sensors & 0 & 0 & 0 & 0 & 0 & 0 & 1000 \\
\hline $\begin{array}{l}1^{\text {st }} \text { Principles } \\
\text { Simulators }\end{array}$ & 100 & 50 & 0 & 0 & 20 & 0 & 50 \\
\hline $\begin{array}{l}\text { Remote Panel } \\
\text { Display/Operation }\end{array}$ & 0 & 50 & 50 & 0 & 0 & 0 & 20 \\
\hline
\end{tabular}

\begin{tabular}{|l|l|}
\hline Technology/Process/Location & \\
\hline $\begin{array}{l}\text { Physical Network Infrastructure } \\
\text { (copper, fiber, wireless, } \text { etc.) }\end{array}$ & \\
\hline & \\
\hline DCS & \\
\hline General I\&C & \\
\hline Alarm Systems & \\
\hline Process Computer & \\
\hline Monitoring Systems & \\
\hline Event Recorder & \\
\hline Supp. Info Network & \\
\hline Computer-based Procedures & \\
\hline Task-Based Displays & \\
\hline Alarm Management & \\
\hline Group View Displays & \\
\hline $\begin{array}{l}\text { Computerized Operator Support } \\
\text { system }\end{array}$ & \\
\hline Plant Status & \\
\hline Virtual Sensors & \\
\hline First Principle Simulators & \\
\hline Remote Panel Display/Operation & \\
\hline & \\
\hline Questions to keep in mind: & \\
\hline Are the numbers real? & \\
\hline $\begin{array}{l}\text { How can we make this useful and } \\
\text { meaningful? }\end{array}$ & \\
\hline
\end{tabular}




\section{Online Monitoring}

\begin{tabular}{|l|c|c|c|}
\hline Components/Structures & Numbers & $\begin{array}{c}\text { Avg. No. of } \\
\text { Sensors }\end{array}$ & Transfer Rate \\
\hline Active Components & 500 & 4 & Once/sec \\
\hline Passive Components & 50 & 10 & Once/day \\
\hline
\end{tabular}

\begin{tabular}{|l|l|}
\hline Technology/Process/Location & \\
\hline $\begin{array}{l}\text { Physical Network Infrastructure } \\
\text { (copper, fiber, wireless, etc.) }\end{array}$ & \\
\hline Sensors - Active & \\
\hline Sensors - Passive & \\
\hline Questions to keep in mind: & \\
\hline Are the numbers real? & \\
\hline $\begin{array}{l}\text { How can we make this useful and } \\
\text { meaningful? }\end{array}$ & \\
\hline
\end{tabular}




\section{Automated Work Functions}

\begin{tabular}{|l|l|l|l|}
\hline Types & Number & $\begin{array}{l}\text { No. of } \\
\text { Points }\end{array}$ & Trans Rate \\
\hline Component Position & 2000 & 1 & Once every 15 min \\
\hline Operating Parameters & 200 & 1 & Once/sec \\
\hline Temporary Instrumentation & 20 & 1 & Once/sec \\
\hline Plant Sampling Packages & 50 & 10 & On-demand $>$ once/hour \\
\hline Data Transmission for Local Gauges & 1000 & 1 & On-demand $>$ once/hour \\
\hline $\begin{array}{l}\text { Data Transmission for Local Alarm } \\
\text { Panels }\end{array}$ & 100 & 100 & On-demand $>$ once/hour \\
\hline $\begin{array}{l}\text { Data Transmission for Local Control } \\
\text { Panels }\end{array}$ & 100 & 15 & On-demand $>$ once/hour \\
\hline Remote Dose Monitors & 200 & 2 & Once/sec \\
\hline
\end{tabular}

\begin{tabular}{|l|l|}
\hline Technology/Process/Location & \\
\hline $\begin{array}{l}\text { Physical Network Infrastructure } \\
\text { (copper, fiber, wireless, etc.) }\end{array}$ & \\
\hline & \\
\hline Component Position & \\
\hline Operating Parameters & \\
\hline Temporary Instrumentation & \\
\hline Plant Sampling Packages & \\
\hline Local Gauges & \\
\hline Local Alarm Panels & \\
\hline Local Control Panels & \\
\hline Remote Dose Monitors & \\
\hline Questions to keep in mind: & \\
\hline Are the numbers real? \\
\hline $\begin{array}{l}\text { How can we make this useful and } \\
\text { meaningul? }\end{array}$
\end{tabular}




\section{Major Applications}

(How much are these interfaced or integrated?)

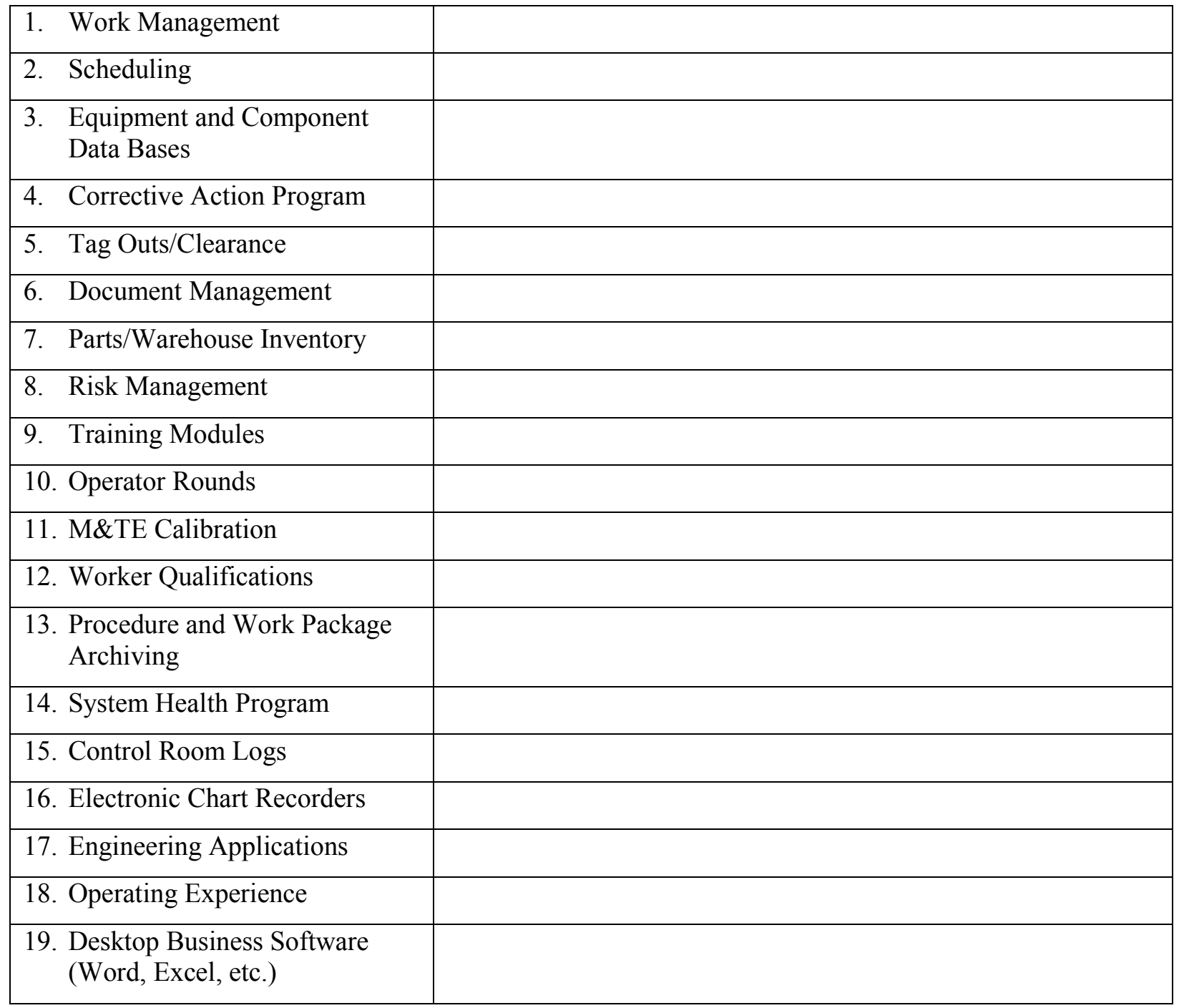




\begin{tabular}{|c|c|}
\hline Types of Communicatio & Systems (Degree of Coverage/Capacity/Speed/etc.) \\
\hline 1. LAN & \\
\hline 2. WAN & \\
\hline 3. Internet & \\
\hline 4. Wireless & \\
\hline 5. Telephone & \\
\hline 6. Radio & \\
\hline 7. Cellular Voice & \\
\hline 8. Cellular Data & \\
\hline 9. SMS & \\
\hline $\begin{array}{l}\text { 10. Process Systems } \\
\text { Networks (Field Bus, } \\
\text { Profibus, etc.) }\end{array}$ & \\
\hline $\begin{array}{l}\text { 11. Other Mobile Device } \\
\text { Networks }\end{array}$ & \\
\hline
\end{tabular}

\section{Mobile Devices}

1. PDA/Cell Phone

2. Tablets

3. Laptops

II. Data Storage and Application Hosting

1. Internal

2. External (Cloud)

3. Hybrid

\section{Control Center Collaboration}

1. Video Streaming

2. Smart Boards

3. Video Conferencing 


\section{Component Identification/Position Technology}

\begin{tabular}{|l|l|}
\hline 1. Bar codes & \\
\hline 2. OCR & \\
\hline 3. RFID & \\
\hline 4. Machine Vision & \\
\hline 5. Position Sensors & \\
\hline V. Cybersecurity & \\
\hline 1. Authentication & \\
\hline 2. Authorization & \\
\hline 3. Accounting & \\
\hline 4. Perimeter & \\
\hline 5. Air Gap & \\
\hline 6. Awareness Training &
\end{tabular}

\section{Performance}

1. Bandwidth/Contention

2. Latency of Data Update

3. Scalability

4. Segmentation

5. Portability (renderings)

6. Connectivity

\section{Plant Data Interface}

1. PI (Vendor OSIsoft)

2. Plant Computer

\section{Plant Automation}

1. Remote Dose Monitoring

2. Automated Sampling Systems

3. Online Condition Monitoring Systems 


\section{Control Centers}

1. Outage Control Center

2. Work Control Center

3. RWP (radiological work permit) Control Center

X. Configuration Management

1. Regulatory Requirements

2. Corporate Policy

XI. Corporate/Nuclear Information Architecture Policies and Standards 
Appendix B

Results from Site Visits 


\section{Appendix B \\ Results from Site Visits}

The researchers gathered a vast amount of information during each of the site visits. A content analysis was conducted to sort the information into categories. The categories were defined as a part of the content analysis process. Sixteen new categories were identified as a part of the content analysis process.

\begin{tabular}{|l|l|}
\hline Number & Category \\
\hline 1 & Network \\
\hline 2 & Electronic Work Packages, Computer-Based Procedures, and Rounds \\
\hline 3 & Mobile Devices \\
\hline 4 & Remote Collaboration \\
\hline 5 & Voice Communication \\
\hline 6 & Text Messaging \\
\hline 7 & Streaming Video \\
\hline 8 & Plant Information \\
\hline 9 & Online Monitoring \\
\hline 10 & Outage Control Center \\
\hline 11 & Technical Support Center \\
\hline 12 & Work Execution Center \\
\hline 13 & Management Decision Support Center \\
\hline 14 & Main Control Room \\
\hline 15 & Work Management System \\
\hline 16 & Warehouse \\
\hline
\end{tabular}

It should be acknowledged that the categories represent various technologies as well as various plant locations where the technologies might be used. In other words, streaming video is a technology that might be used in any or all of the control centers. "No comments were captured" indicates that no information in the specific category was captured during the site visit.

\begin{tabular}{|l|l|}
\hline & 1. Network \\
\hline Utility 1 & $\begin{array}{l}\text { Fiber. } \\
\text { Office buildings have wireless network. } \\
\text { No permanent wireless network in the plant, except for the warehouse. }\end{array}$ \\
\hline Utility 2 & $\begin{array}{l}\text { Optical or fiber. } \\
\text { Office buildings have wireless network. } \\
\text { Wireless is not allowed in the power block. }\end{array}$ \\
\hline Utility 3 & $\begin{array}{l}\text { Office buildings have wireless network. } \\
\text { Main control room is a wireless exclusion zone. }\end{array}$ \\
\hline
\end{tabular}




\begin{tabular}{|l|l|}
\hline & 2. Electronic Work Packages, Computer-based Procedures, and Rounds \\
\hline Utility 1 & $\begin{array}{l}\text { An electronic work package (eWP) process is not in the near future plans. } \\
\text { AutoLog is used in the main control room and AutoTour is used for operations rounds in } \\
\text { the plant. } \\
\text { Pushing to get an updated version of the work management system (WMS). The WMS } \\
\text { vendor will incorporate capabilities similar to the existing eWP products. }\end{array}$ \\
\hline Utility 2 & Developed a prototype for an eWP system, which they hope to get approved and funded. \\
\hline Utility 3 & $\begin{array}{l}\text { In discussion with vendors regarding eWPs and computer-based procedures for field } \\
\text { workers. }\end{array}$ \\
\hline
\end{tabular}

\begin{tabular}{|l|l|}
\hline Utility 1 & $\begin{array}{l}\text { 3. Mobile Devices } \\
\text { Windows to use mobile devices in the plant. } \\
\text { Blackberries and iPhones are allowed. }\end{array}$ \\
\hline Utility 2 & $\begin{array}{l}\text { Approves of containerized environment on both iOS and Android devices. } \\
\text { Only to be used for business purposes at this point. } \\
\text { About 990 nuclear devices in the Airwatch program. }\end{array}$ \\
\hline Utility 3 & $\begin{array}{l}\text { About 70\% of the staff uses mobile devices for business purposes (e.g., email, calendar, } \\
\text { limited access to the WMS). } \\
\text { Mobile devices are currently only allowed on the business process side. } \\
\text { Mobile devices (not connected to the network) are used to take readings in the plant. }\end{array}$ \\
\hline
\end{tabular}

\begin{tabular}{|l|l|}
\hline & 4. Remote Collaboration \\
\hline Utility 1 & $\begin{array}{l}\text { Will update Windows next year and hence get access to the Microsoft native real-time } \\
\text { collaboration and document sharing tool. } \\
\text { No plans to use the Windows tool for collaboration. } \\
\text { Uses a video conference application for interview purposes. }\end{array}$ \\
\hline Utility 2 & $\begin{array}{l}\text { A mobile application for observations (developed in-house) is used at the plants. The } \\
\text { application has the capability to send photos from the field directly to the decision makers. } \\
\text { Microsoft native collaboration tool is blocked on all desktops. }\end{array}$ \\
\hline Utility 3 & $\begin{array}{l}\text { Has had touchpanels/smartboards for years, but are only used to project images. } \\
\text { Uses conferencing tools such as a web conferencing application and a real-time document } \\
\text { sharing tool to collaborate within and outside the plant. }\end{array}$ \\
\hline
\end{tabular}




\begin{tabular}{|l|l|}
\hline & 5. Voice Communications \\
\hline Utility 1 & $\begin{array}{l}\text { The cellular network was recently upgraded adding coverage in most areas in the power } \\
\text { block. } \\
\text { Both iPhones and Blackberries are allowed in the protected area. } \\
\text { The emergency response organization is now using company issued Blackberries instead of } \\
\text { pagers. }\end{array}$ \\
\hline Utility 2 & $\begin{array}{l}\text { Voice Over Internet Protocol (VOIP) is not used, but some of the plants have it in their } \\
\text { future plans. } \\
\text { Uses mini cell towers to get cellular coverage in the plant. } \\
\text { There is some cellular coverage in the power block, but not everywhere. } \\
\text { Tried the Vocera technology, but decided that it did not work well for them. }\end{array}$ \\
\hline Utility 3 & $\begin{array}{l}\text { Administrative procedures need to be revised to allow cell phones in the plant. } \\
\text { Cellular is not 100\% available throughout the plant. } \\
\text { Uses radios in the plant. } \\
\text { Had some success with Vocera push to talk technology }\end{array}$ \\
\hline
\end{tabular}

\begin{tabular}{|l|l|}
\hline & 6. Text Messaging \\
\hline Utility 1 & $\begin{array}{l}\text { Text messaging is used for individual communications, but it is not used as a part of the } \\
\text { business process. }\end{array}$ \\
\hline Utility 2 & $\begin{array}{l}\text { Instant messages are used via office desktop computers. } \\
\text { The instant messaging software can also be used to send messages to cellphones. }\end{array}$ \\
\hline Utility 3 & $\begin{array}{l}\text { Text messaging is not used in the plant, but it is used for business purposes. } \\
\text { If future applications such as electronic work packages and computer-based procedures } \\
\text { automatically provide progress and system status updates to interested parties the need for } \\
\text { text messages will be reduced. }\end{array}$ \\
\hline
\end{tabular}

\begin{tabular}{|l|l|}
\hline & 7. Streaming Video \\
\hline Utility 1 & The business network is used to stream temporary video feeds from the field. \\
\hline Utility 2 & $\begin{array}{l}\text { Video has been identified as a big driver for how to design infrastructure capabilities. For } \\
\text { example, one of the plants has } 200 \text { cameras installed. } \\
\text { Recognizes that all cameras should be multicast; however, right now this is not the case. } \\
\text { Some of the plants the cameras are on a closed connection while other plants have the } \\
\text { camera feed on the business network. }\end{array}$ \\
\hline Utility 3 & Video streaming is the real bottleneck in the infrastructure. \\
\hline
\end{tabular}




\begin{tabular}{|l|l|}
\hline & 8. Plant Information (PI) \\
\hline Utility 1 & In the future the values recorded via the OLM process will be fed to the PI system. \\
\hline Utility 2 & $\begin{array}{l}\text { The I\&C data ships out through PI. } \\
\text { Recognizes the issue of using this data for decision making purposes due to the time delay } \\
\text { between actual plant status and the updates to the PI system. }\end{array}$ \\
\hline Utility 3 & $\begin{array}{l}\text { The PI system can support almost real-time plant data. } \\
\text { The refresh rate is once per second, hence the data in PI is 1 second old. This is probably } \\
\text { good enough for most applications (e.g., electronic work packages and computer-based } \\
\text { procedures) that would use plant data in some way. } \\
\text { System status can be retrieved from PI. } \\
\text { The data in the PI system is stored for 1 year. }\end{array}$ \\
\hline
\end{tabular}

\begin{tabular}{|l|l|}
\hline Utility 1 & $\begin{array}{l}\text { 9. Online Monitoring (OLM) } \\
\text { OLM is used for vibration monitoring of components such as the reactor coolant pumps, } \\
\text { turbine generators, and the turbine feed. } \\
\text { Most monitoring is still conducted on a need basis by engineers in the plant. }\end{array}$ \\
\hline Utility 2 & $\begin{array}{l}\text { The issue of no wireless network access in the power block should be resolved before they } \\
\text { can expand the OLM activities. } \\
\text { Looking at technology options to be used as a supplement to PRISM. }\end{array}$ \\
\hline Utility 3 & $\begin{array}{l}\text { Mobile devices are used to take readings in the plant. } \\
\text { The future plan is to have component sensors transfer values over the wireless network, } \\
\text { which automatically updates plant databases. } \\
\text { Data storage could be a challenge with OLM. }\end{array}$ \\
\hline
\end{tabular}

\begin{tabular}{|l|l|}
\hline & 10. Outage Control Center (OCC) \\
\hline Utility 1 & $\begin{array}{l}\text { The OCC is basic. } \\
\text { Schedule and video streams are displayed on large displays. } \\
\text { There are phones, workstations, and an overhead projector in the OCC. } \\
\text { There is no video conferencing capability in the OCC. } \\
\text { The OCC room is also used for the Operations Support Center. } \\
\text { Currently, there are no plans to upgrade the OCC. }\end{array}$ \\
\hline Utility 2 & $\begin{array}{l}\text { There are smartboards in all OCCs used for displaying information to everyone in the room } \\
\text { plus to all managers. }\end{array}$ \\
\hline Utility 3 & Uses OneNote to communicate status between the OCC and home organizations. \\
\hline
\end{tabular}




\begin{tabular}{|c|c|}
\hline & 11. Technical Support Center (TSC) \\
\hline Utility 1 & The TSC has video conferencing capabilities. \\
\hline Utility 2 & $\begin{array}{l}\text { Everything conducted in the TSC is computer-based. } \\
\text { If it was possible to remote in to the TSC it could probably be run from laptops. } \\
\text { Most of the TSC, Operations Support Center, and the Emergency Operations Facility } \\
\text { already have smartboards, projectors, and desktops. } \\
\text { No plans for further modernization. }\end{array}$ \\
\hline Utility 3 & No comments were captured. \\
\hline
\end{tabular}

\begin{tabular}{|c|c|}
\hline & 12. Work Execution Center (WEC) \\
\hline Utility 1 & No comments were captured. \\
\hline Utility 2 & No comments were captured. \\
\hline Utility 3 & $\begin{array}{l}\text { Most work statusing is conducted in the WEC, not in the OCC. } \\
\text { Uses Tempo for statusing work orders. } \\
\text { All clearance work orders come out of the WEC, which pose a tremendously high load on } \\
\text { the center during outage. }\end{array}$ \\
\hline
\end{tabular}

\begin{tabular}{|l|l|}
\hline & 13. Management Decision Support Center \\
\hline Utility 1 & The management decision support center has video conferencing capabilities. \\
\hline Utility 2 & $\begin{array}{l}\text { Would save \$1.6M per year if all participants in the "plan of the day" meeting viewed the } \\
\text { daily reports on iPads instead of printing paper copies. } \\
\text { A mobile application to support the plan of the day meeting has been developed in-house } \\
\text { and is used on iPads at some plants. } \\
\text { Other plants use projectors and paper copies. }\end{array}$ \\
\hline Utility 3 & No comments were captured. \\
\hline
\end{tabular}

\begin{tabular}{|l|l|}
\hline & 14. Main Control Room (MCR) \\
\hline Utility 1 & $\begin{array}{l}\text { No plans for digital upgrades in the MCR. } \\
\text { The possible potential upgrades are limited due to the original design on the MCR and } \\
\text { restrictions resulting from previous I\&C upgrades. }\end{array}$ \\
\hline Utility 2 & $\begin{array}{l}\text { All workstations in the MCR are on Level } 2 \text { network. The technologies suggested by the } \\
\text { LWRS program would have to be on Level } 3 \text { or } 4 .\end{array}$ \\
\hline Utility 3 & $\begin{array}{l}\text { No short-term plans to upgrade the MCR. } \\
\text { Might consider it in the future. }\end{array}$ \\
\hline
\end{tabular}




\begin{tabular}{|l|l|}
\hline & 15. Work Management System \\
\hline Utility 1 & $\begin{array}{l}\text { The WMS supports processes such as the corrective action program, clearances, and } \\
\text { condition reports. } \\
\text { During an outage the system can have up to } 350 \text { users at one time. } \\
\text { The WMS has some advanced technology capabilities, such as 2D and 3D models, } \\
\text { integrated final safety analysis report (FSAR) requirements, and tracking of commitments. } \\
\text { The WMS vendor is currently developing an electronic condition report process using } \\
\text { Quick Response (QR) codes. }\end{array}$ \\
\hline Utility 2 & No comments were captured. \\
\hline Utility 3 & The WMS is accessible from any device that can connect to the network. \\
\hline
\end{tabular}

\begin{tabular}{|l|l|}
\hline & 16. Warehouse \\
\hline Utility 1 & See Network. \\
\hline Utility 2 & No comments were captured. \\
\hline Utility 3 & $\begin{array}{l}\text { Has an immediate need for a supply chain application that would leverage radio-frequency } \\
\text { identification (RFID) technology to track inventory. }\end{array}$ \\
\hline
\end{tabular}

\section{Additional Comments}

Utility 1 includes indirect staff such as IT, human resources, legal, and procurement as a part of the augmentation staff. This adds about 100 individuals on top of the contractors.

About 600 contractors are augmented for an outage.

Utility 1 stated that the older generation of plant workers is reluctant to change, which makes it challenging to propose and implement new technology.

There are inconsistencies within Utility 2's plants that must be addressed and resolved before moving forward with technology on a fleet wide scale. Currently, theses inconsistencies are addressed on a case-by-case basis. An example of inconsistency is the different definition of what a critical digital asset is and what is not within Utility 2.

One reason why people are reluctant to embrace a data center concept is the notion that one must be able to operate the plant without access to the outside world.

The IT department has great ideas, but should be much better at justifying the return on investment.

The Internet of things; everyone will be using multiple devices.

The culture (e.g., demographic, "big brother," fear of new technology, and cybersecurity approaches) should be considered when planning changes to the infrastructure.

The challenge is not what can be done from a technical standpoint, the challenge lays in what will be allowed to do both from a cybersecurity and regulator point of view.

Utility 2 wanted to build a fiber highway around the plant with access points into the plant. There was a big push for this 7 years ago, but it was not successful. IT is now trying to push for this again. It is aggressive since not everyone understands the need for the underlying structure before deploying advanced technology.

Money is not the main issue; it is the ability to get anything through the process that is the issue. How do you prioritize a highway fiber project over replacing a 30-year-old component?

Utility 3 questioned how the operator-support technologies would be captured in the design of the digital architecture since there are currently only hardwired connections in the MCR. 


\section{Appendix C}

\section{Web-Based Survey}




\section{Appendix C \\ Web-Based Survey}

NPP Digital Architecture Questionnaire

Welcome to the NPP Digital Architecture Questionnaire.

Thank you for taking the time to help advance our research effort. Your feedback plays an important part in the development of an industry consensus model for digital architectures!

Best regards,

The INL Team

* 1. Participant information:

Company

Plant



Next

Powered by

SurveyMonkey

See how easy it is to create a survey. 
NPP Digital Architecture Questionnaire

\section{* 2. Are there any of the following technologies at your site?}

Wireless network in the
plant
Multicast of video feeds
SMS (text messaging) for
business purposes
Social media for business
purposes
Video cameras for
monitoring plant work
activities
Large displays in control
centers (outage control
center, work control center,
etc.

Touch/interactive

displays in control centers

(outage control center,

work control center, etc

Real-time collaboration tools (WebEx,

GoToMeeting, BlueJeans,

etc.)

Document sharing tools

(Google Drive, OneDrive,

etc)

Notebook service

(OneNote, EverNote, etc.)

Mobile devices

Voice Over Internet

Protocol (NOIP) 
NPP Digital Architecture Questionnaire

* 3. Where/how is the technology being used (or is planned to be used)? Mark all that apply.

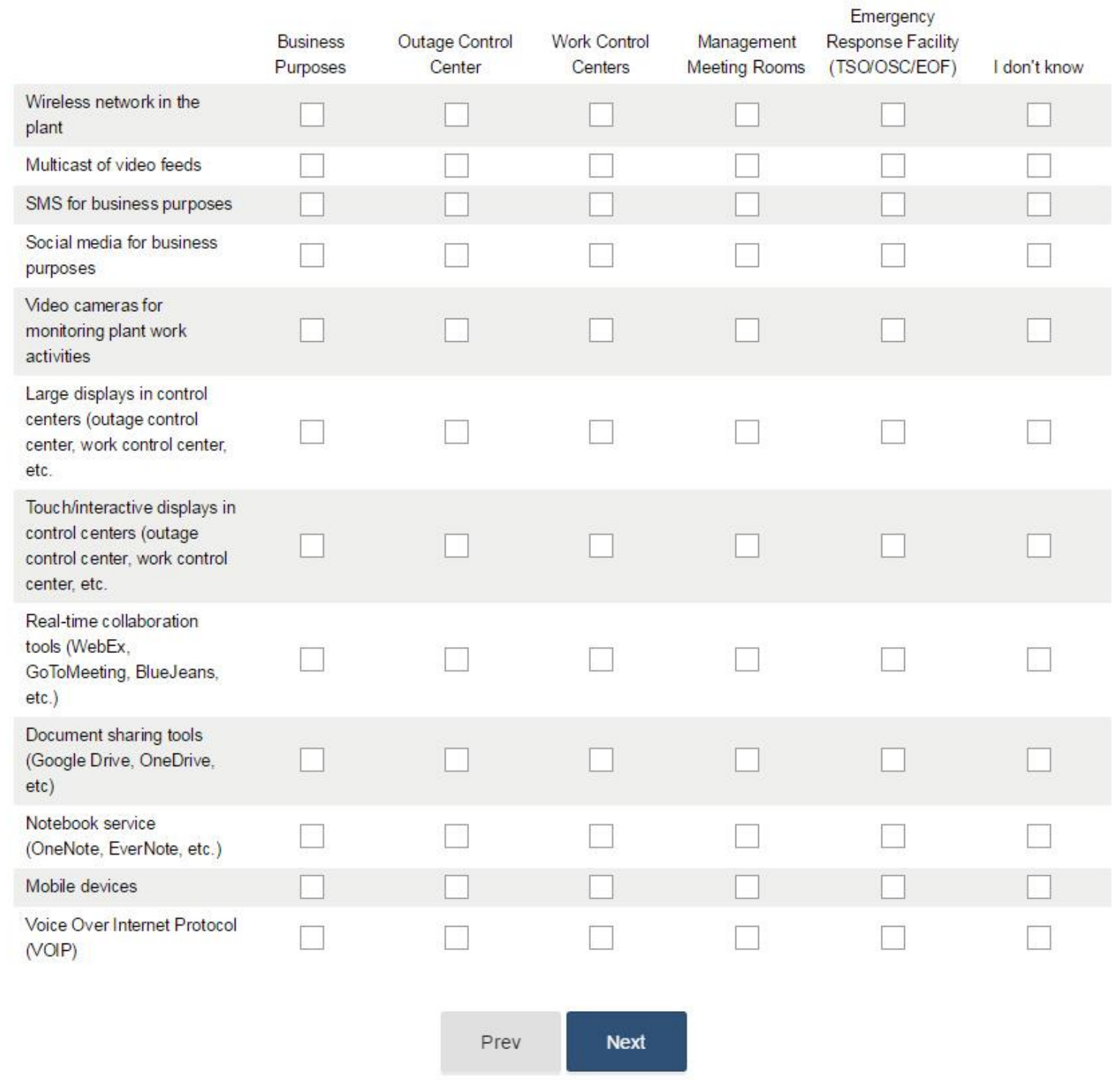




\section{NPP Digital Architecture Questionnaire}

\section{* 4. Are you pursuing any of the following mobile worker technologies?}

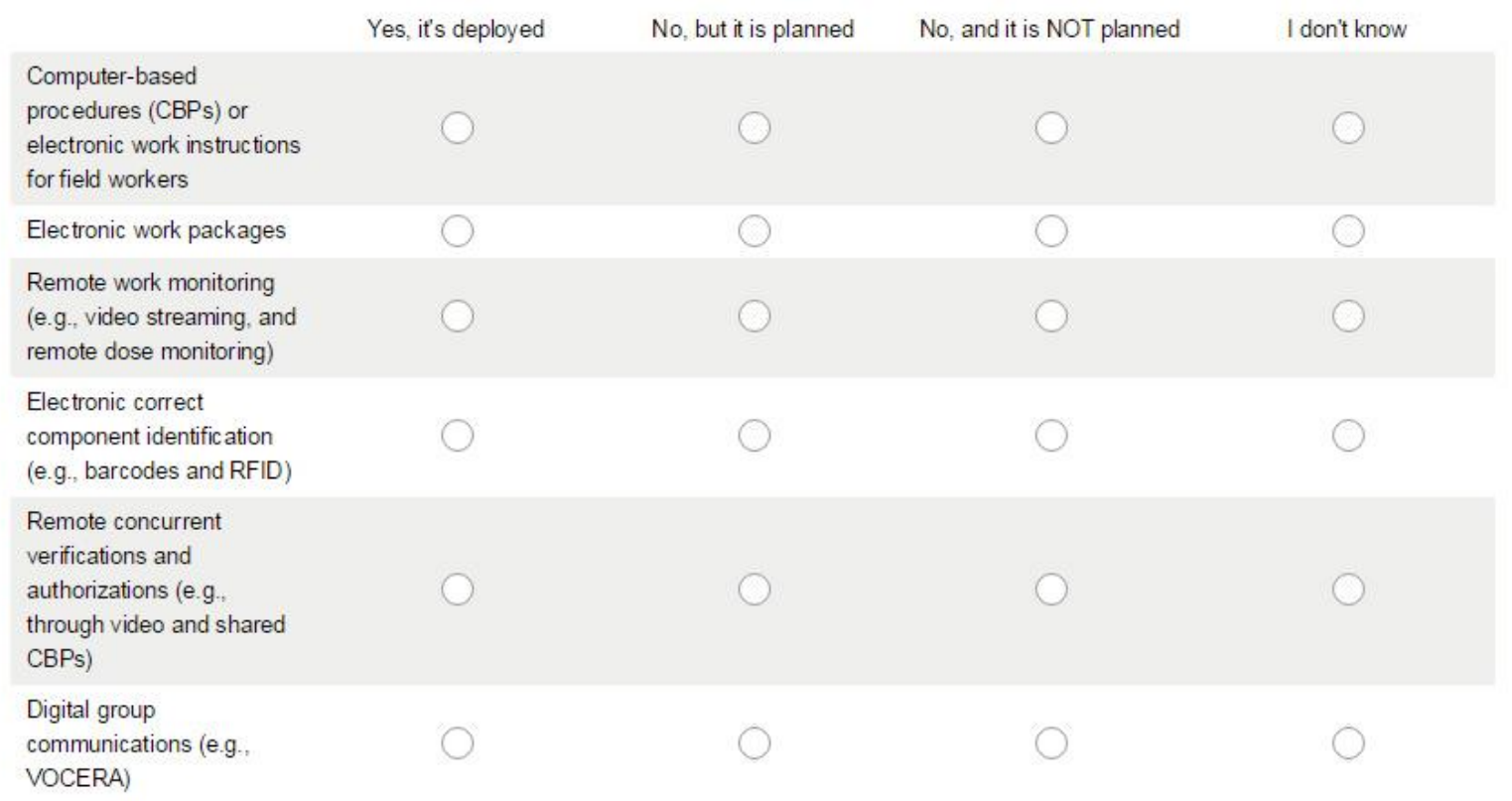

* 5. Is there a policy for user to use personal devices at your site/plant?

Powered by

m. SurveyMonkey

See how easy it is to create a survey. 
NPP Digital Architecture Questionnaire

* 6. Are you pursuing on-line monitoring technologies?

Continuous component
condition monitoring
technologies in lieu of
periodic surveillances
Centralized on-line
monitoring center to
analyze data coming from
monitoring technologies

* 7. Are you pursuing technologies that offset manually-performed work activities?

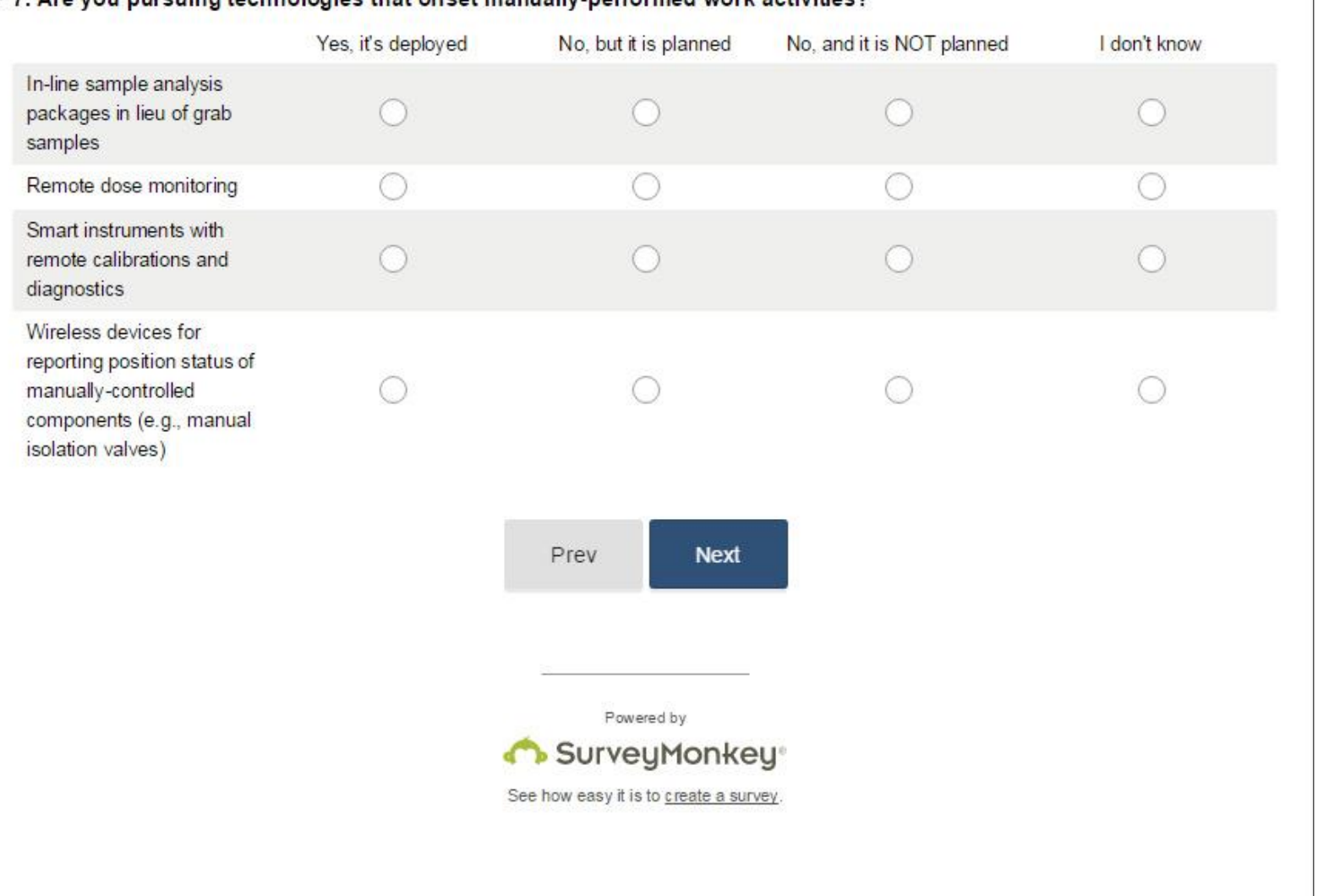




\section{NPP Digital Architecture Questionnaire}

* 8. Are you pursuing advanced control room technologies?

Advanced alarm
processing
Control room computer-
based procedures
Information rich displays
Distributed control systems
On-line monitoring for plant
components

Powered by

m. SurveyMonkey

See how easy it is to create a survey. 
NPP Digital Architecture Questionnaire

* 9. Do you see cyber-security as a limiting factor for deploying wireless?

Yes, because.

No, because.

10. Any additional issues, questions, or topics INL should address to make the Digital Architecture effort even more useful to the you and then nuclear industry?

11. Do you have any additional comments or information to share with us?

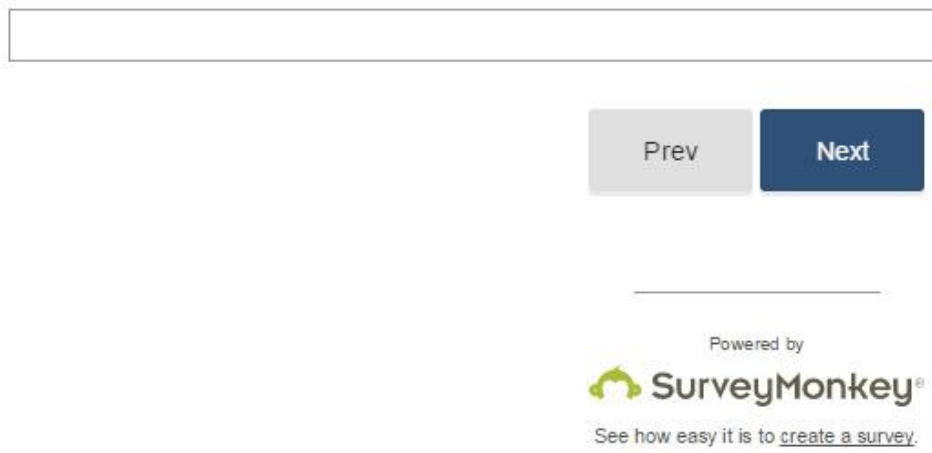

NPP Digital Architecture Questionnaire

12. (Optional) If you are interested in sharing more information with us, please provide the following contact information.

Name

Email Address

Phone Number

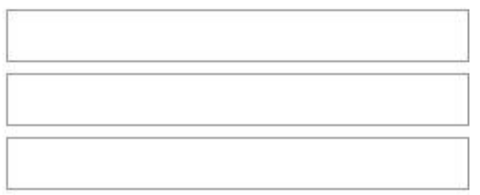

Powered by

\section{SurveyMonkey}


Appendix D

\section{Result from Web-Based Survey}




\section{Appendix D \\ Results from Web-Based Surveys}

\section{Participants' Affiliation}

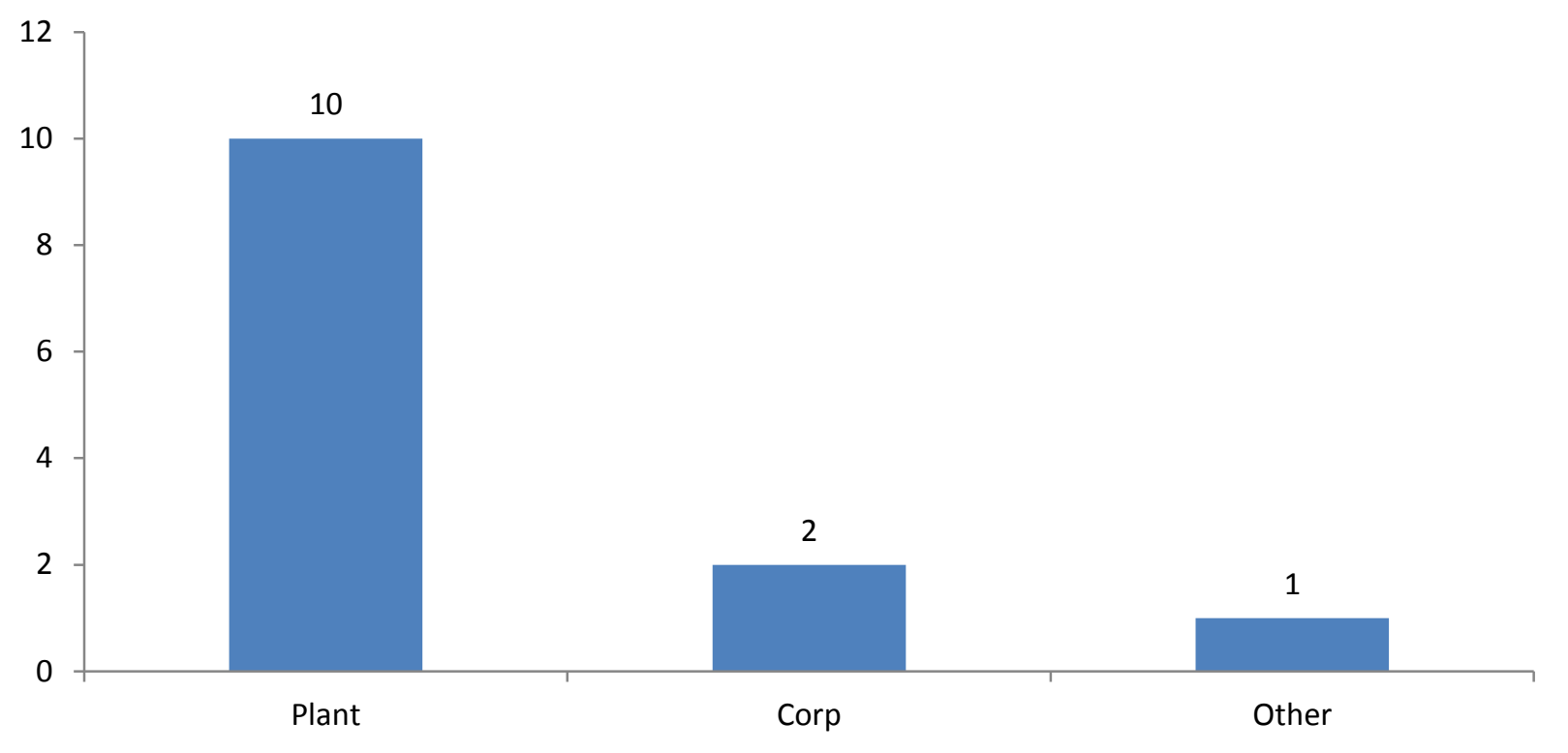

\section{Are there any of the following technologies at your site?}

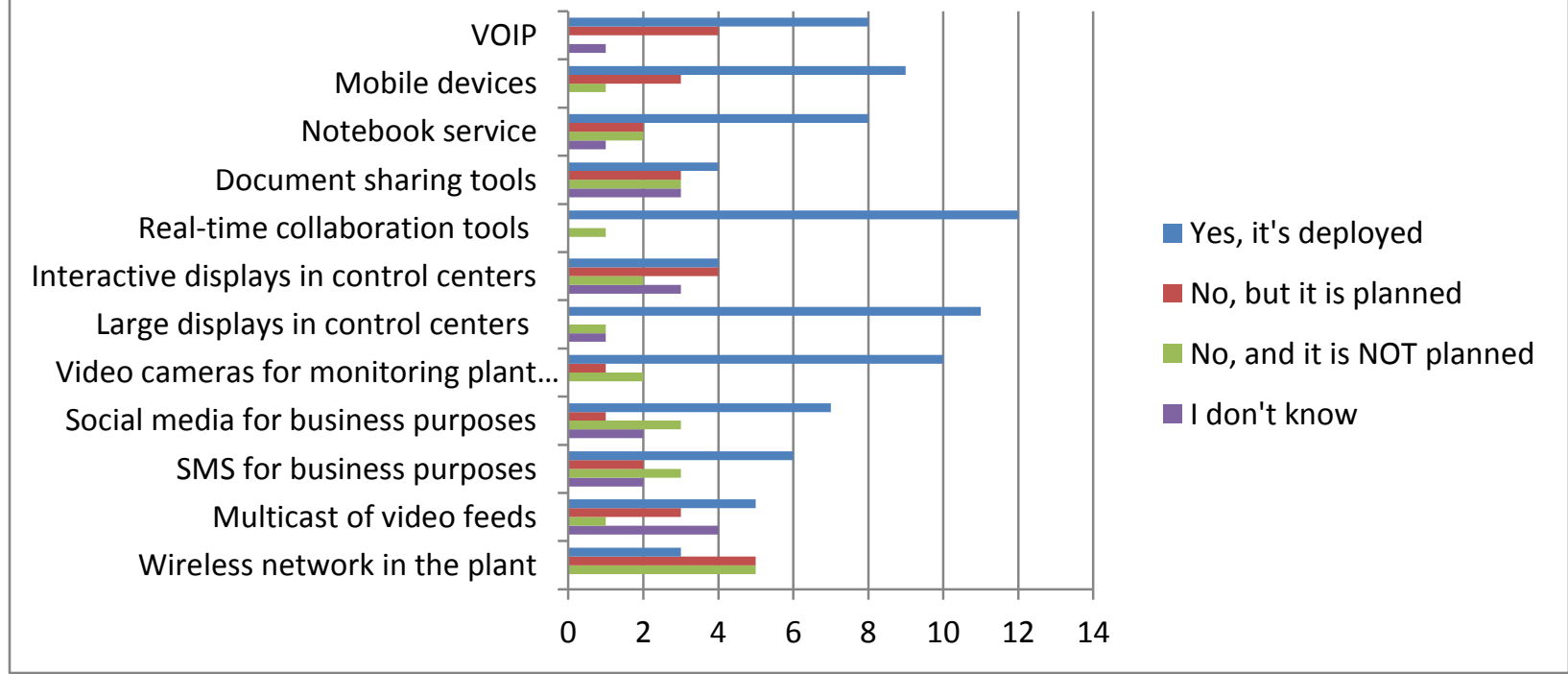




\section{Where/how is the technology being used (or is planned to be used)?}

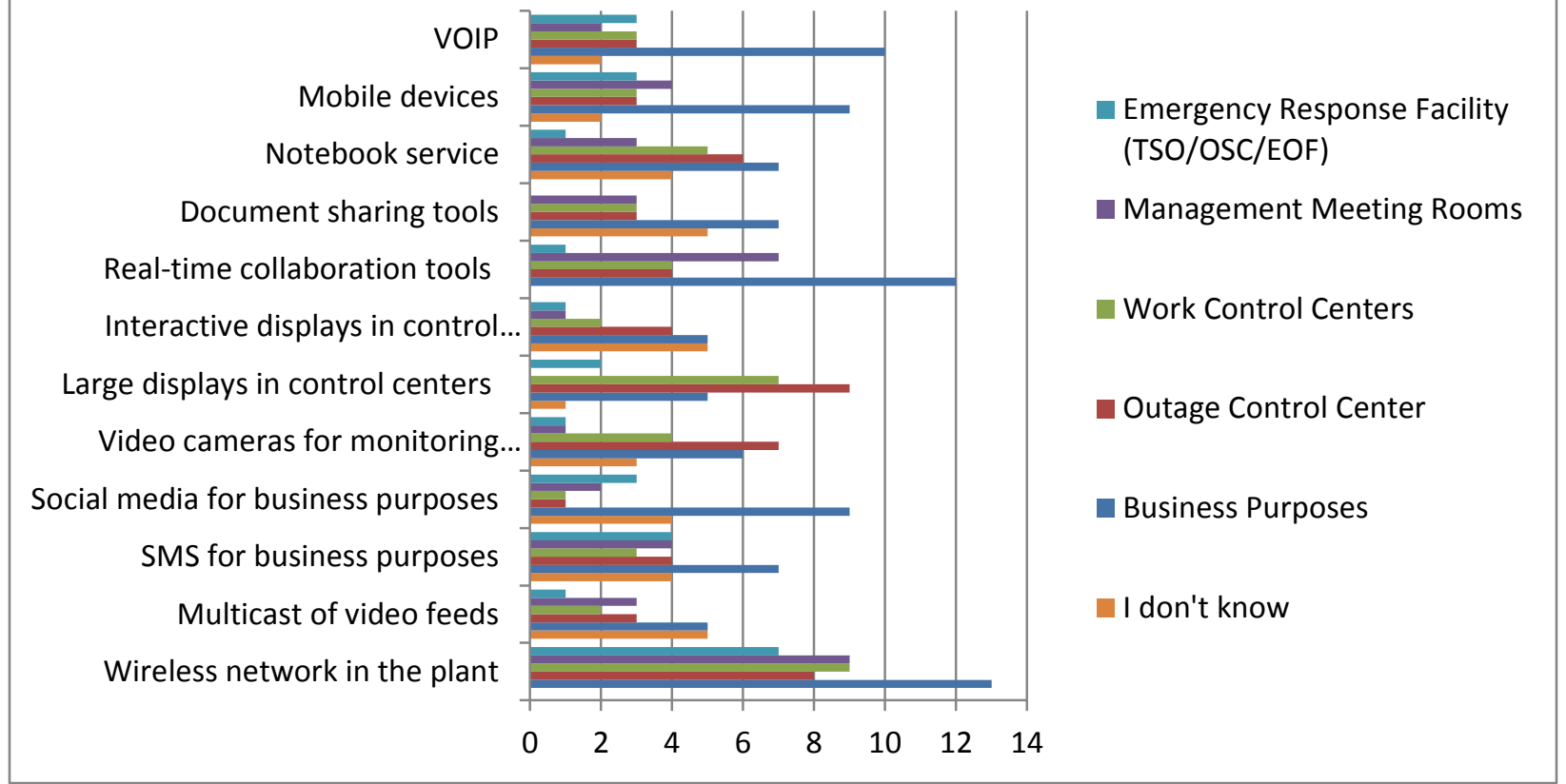

\section{Are you pursuing technologies that offset manually-performed work activities?}

Wireless devices for reporting position status of manually controlled components

Smart instruments with remote calibrations and diagnostics

Remote dose monitoring



Yes, it's deployed

No, but it is planned

$\square$ No, and it is NOT planned

I don't know

In-line sample analysis packages in lieu of grab samples 


\section{Are you pursuing advanced control room technologies?}
